\title{
2. Nature's Contributions to People and Human Well-being in a Nordic coastal context
}

Lead author: Henrik Svedäng. Contributing authors: Monica Hammer, Anna Stiina Heiskanen, Maija Häggblom, Hannele Ilvessalo-Lax, Marie Kvarnström, Håkan Tunón, Petteri Vihervaara.

Box 2: Summary

In this chapter, essential ecological and societal aspects of the Nordic coastal environment are highlighted. These show that local communities and stakeholders need to be more involved in decision-making because their needs and their ecological knowledge are essential to this process. This also relates to Aichi targets $14,15,16$ and 18 (see Lucas et al., 2015). There is the need to improve the monitoring of all types of NCP or ecosystem services and to critically review existing indicators that may be used to track the development of biodiversity and NCP. Only by actively analysing data and creating syntheses, is it possible to understand changes in the ecosystem linking biodiversity and NCP.

\subsection{Introduction}

IPBES assessments intend to promote conservation and sustainable use of biodiversity, long-term human well-being and sustainable development (UNEP, 2006; Böhnke et al., 2016). The key elements of the conceptual framework in IPBES assessments are nature (to which human beings belong), the contributions that people gain from living in and interacting with nature and a high quality of life (Diaz et al., 2015; Maes et al., 2013; 2014). The regional focus of the current assessment is the Nordic coastal environment, which includes both the land-side of the coastal zone, as well as the marine environment. Nordic coastal environments are assessed using this IPBES platform (Gundersen et al., 2006), nature's contributions to people (NCP) and human well-being by exploring and describing the connections between the natural coastal and marine world and human societies in these biocultural environments. The seascape and the landscape, as well as the species composition in most of these areas, are the results of both the physical constitution and human resource utilisation, including the cultural aspects of harvesting of NCP (Haines-Young \& Potschin, 2010).

In the context of science, the natural world includes biodiversity and ecosystems, ecosystem productivity and functioning, evolution, humanity and biocultural diversity (e.g. Bridgewater, 2017). To other knowledge-systems, it includes categories such as Mother Earth and systems of life (IPBES 2017). It is essential to emphasize that humans 
are an integrated part of all studied Nordic coastal areas, not only as agents behind direct and indirect drivers of change, but with their socio-cultural diversity affecting and promoting biodiversity (Hasler et al., 2016).

\subsubsection{What is human well-being and good quality of life?}

Human well-being is often defined as the state of physical and mental health of individuals (Chan et al., 2016). Common indicators of human well-being, such as income and per capita gross domestic product (GDP), are informative because average values per person per country are often correlated with child mortality, life expectancy and the human development index (Diaz et al., 2015). Nonetheless, they are often criticised for only capturing a small proportion of the many attributes of the current concept of well-being.

Some indicators covering the various aspects of well-being are now available, including the genuine progress indicator, inclusive wealth index, OECD good life indicator and the coefficient of living standard among others (Duraiappah \& Muños, 2012; Kubiszewski et al., 2013; Costanza et al., 2014). Freedom of choice and action is influenced by other constituents of well-being and is also a precondition for achieving different components of well-being, particularly concerning equity and fairness (MEA, 2005).

IPBES intends to offer indicators on the ethical and ecologically sustainable utilization of nature as key components of the concept of human well-being (Diaz et al., 2015). "Good quality of life" can be described as the accomplishment of a fulfilled human life. A "good quality of life" is multidimensional, with both material and immaterial components. The case studies (Tunón (Ed.), 2018) in this Nordic IPBES-like study, tell how essential the coastal regions are to the Nordic countries (Table 1). In all case studies, fishing is a characteristic NCP, both for the provision of food and in a cultural context. The majority of people in the Nordic countries dwell in the coastal zone (Eurostat, 2017). Also, the coastal zones are economically wealthier and the employment situation is better than inland areas in all Nordic countries (as GDP per inhabitant; Eurostat 2017). In Denmark and Norway, the value of the seafood industry is among the highest in the EU, indicating that this NCP provides a considerable economic benefit for these nations. In Norway, particularly aquaculture has high commercial value. Further, the regulatory, recreational and cultural significance of coastal and marine environments are vital in the Nordic countries and elsewhere in the Baltic Sea littoral states (Czajkowski et al., 2015). 
Table 2: Comparative table of nature's contributions to people that are highlighted in the case studies

\begin{tabular}{|c|c|c|c|c|c|c|c|c|c|}
\hline $\begin{array}{l}\text { Nature's Contribution to } \\
\text { People }\end{array}$ & $\begin{array}{l}\text { The } \\
\text { Quark }\end{array}$ & Kalix & Nätäämö & Lumparen & $\begin{array}{l}\text { Puruvesi } \\
\text { lake }\end{array}$ & $\begin{array}{l}\text { The } \\
\text { Sound }\end{array}$ & $\begin{array}{l}\text { Helge- } \\
\text { land }\end{array}$ & $\begin{array}{l}\text { Faroe } \\
\text { Islands }\end{array}$ & $\begin{array}{l}\text { Disko } \\
\text { Bay }\end{array}$ \\
\hline \multicolumn{10}{|l|}{ Provisioning } \\
\hline Fishing and other sea products & $x$ & $x$ & $x$ & $x$ & $x$ & $x$ & $x$ & $x$ & $x$ \\
\hline Herding & & $x$ & $x$ & & & $x$ & & $x$ & \\
\hline Agriculture & $x$ & $x$ & $x$ & $x$ & & $x$ & $x$ & & \\
\hline Energy & $x$ & & & & & $x$ & $x$ & & $x$ \\
\hline Livelihood & $x$ & $x$ & $x$ & & $x$ & $x$ & $x$ & $x$ & $x$ \\
\hline \multicolumn{10}{|l|}{ Regulatory \& supporting } \\
\hline Climate \& biochemical cycles & $x$ & $x$ & & $x$ & & $x$ & $x$ & & $x$ \\
\hline Resilience & $x$ & $x$ & & & & $x$ & $x$ & $x$ & $x$ \\
\hline Biological functions & $x$ & $x$ & $x$ & $x$ & $x$ & $x$ & $x$ & & $x$ \\
\hline \multicolumn{10}{|l|}{ Cultural } \\
\hline Recreational \& aesthetical & $x$ & $x$ & & $x$ & & $x$ & $x$ & & $x$ \\
\hline Tourism & $x$ & $x$ & & $x$ & & $x$ & $x$ & $x$ & $x$ \\
\hline Social life, wellness & $x$ & $x$ & $x$ & $x$ & $x$ & $x$ & $x$ & $x$ & $x$ \\
\hline Existential & $x$ & $x$ & $x$ & & $x$ & & $x$ & $x$ & $x$ \\
\hline
\end{tabular}

Source: Volume 2, page 16, Table 1, Tunón (Ed.) 2018.

\subsubsection{Description of the Nature's Contributions to People (NCP)}

IPBES defines three broad categories of nature's contributions: regulating contributions, material contributions and non-material contributions. NCP include provisioning services such as food and water, regulating services that affect climate, floods, disease, waste and water quality, cultural services that provide recreational, aesthetic and spiritual benefits, and supporting services such as photosynthesis and nutrient cycling. In the Nordic coastal case studies, NCP are related to a plethora of services:

- Wild living resources such as fish, marine invertebrates, mushrooms, berries, birds and mammals constitute a vital part of NCP in all case studies and especially in the ILK studies. Fishing, hunting and picking of berries and mushrooms for the provisioning of food is an important aspect, as well as a prerequisite for many recreational activities, an intergenerational transfer of knowledge and a part of cultural behaviour (Bridgewater 2017);

- Energy production from the coast by wind, wave, algae (gas production through fermentation of harvested epiphytes) and the use of seawater heat storage are increasingly important aspects of coastal NCP;

- Mediation of waste and toxins: mediation by biota and ecosystems such as mussel beds, kelp forests and eelgrass or Chara meadows, the ability to remove or store pollutants;

- Physical, spiritual, symbolic, aesthetic and intellectual interaction with biota, ecosystems and landscapes: All studied Nordic cases include ILK that underscore the significance of the cultural heritage, diversity and experience of silence, 
beauty and relaxation. These NCP also underpin services in leisure, recreation and tourism;

- Regulatory services: Coastal seas may mitigate variations in the local climate and recycle nutrients. For instance, predatory fish play a regulatory role by mitigating eutrophication through preventing trophic cascades, leading to too high an epiphytic production (Moksnes et al., 2008).

\subsubsection{The history behind the term NCP}

IPBES decided in March 2017 to rename nature's benefits to people to nature's contributions to people. This decision was based on two arguments: 1) The word "benefits", with its strongly positive connotation, wrongly conveyed the idea that negative contributions from nature towards people's good quality of life would be excluded; 2) The different meanings of the word "benefits" in common speech in different languages as well as in the social sciences and the valuation literature represented potential sources of confusion. It was therefore proposed that the name nature's benefits to people would be changed to nature's contributions to people (NCP), while retaining the same meaning and conceptualization as in Díaz et al. (2015), in accordance with the IPBES conceptual framework.

\subsection{Relationships and impacts of changes regarding nature's contributions to people}

\subsubsection{Food security}

Food security concerns both whether the food we eat is safe and healthy, and whether there is a long-term supply of food for our needs $(F A O, 2002)$. Currently, the supplies of food are secured through domestic production and import in the Nordic countries. However, there are still threats to food security due to the spread of hazardous substances in the marine environment, such as mercury and dioxins, which remains a matter of concern for health reasons (e.g. Sheehan et al., 2014). Plastic is an increasing challenge; it is harmful to seabirds that pick plastics from the sea surface such as fulmars (Fulmarus glacialis; Trevail et al., 2015). Microplastics in the Arctic is of increasing concern, partly related to climate change, as sea ice extent is becoming reduced and thus releasing microparticles (Lusher et al., 2015).

Climate change may threaten food security by changes in productivity, distribution of species, expansion of parasites etc. (see Chapter 4). Also, the depletion of fish stocks is a matter of concern. For several decades, various fish stocks from different parts of the Nordic seas have been overfished, such as the large spring spawning Norwegian herring stock (Clupea harengus) (e.g. Dragesund et al., 2012). Fishing also drastically reduced the predatory fish stocks along the Swedish west coast in the late zoth century and to this day, no recoveries have been recorded (Svedäng, 2003; Svedäng \& Bardon, 2003; Cardinale et al., 2012, Fig. 11). In the Baltic Sea, cod (Gadus morhua) stocks (ICES, 
2017) and coastal species such perch (Perca fluviatilis) and eel (Anguilla anguilla) are in a low-productive state (e.g. Svedäng \& Hornborg, 2017).

Figure 11: Historical trends of (a) total official ICES landings, (b) adult biomass [in relative scale], and (c-d) average maximum length (Lmax in $\mathrm{cm}$ with 25 and 75 percentile) for haddock and pollack in the Skagerrak and Kattegat
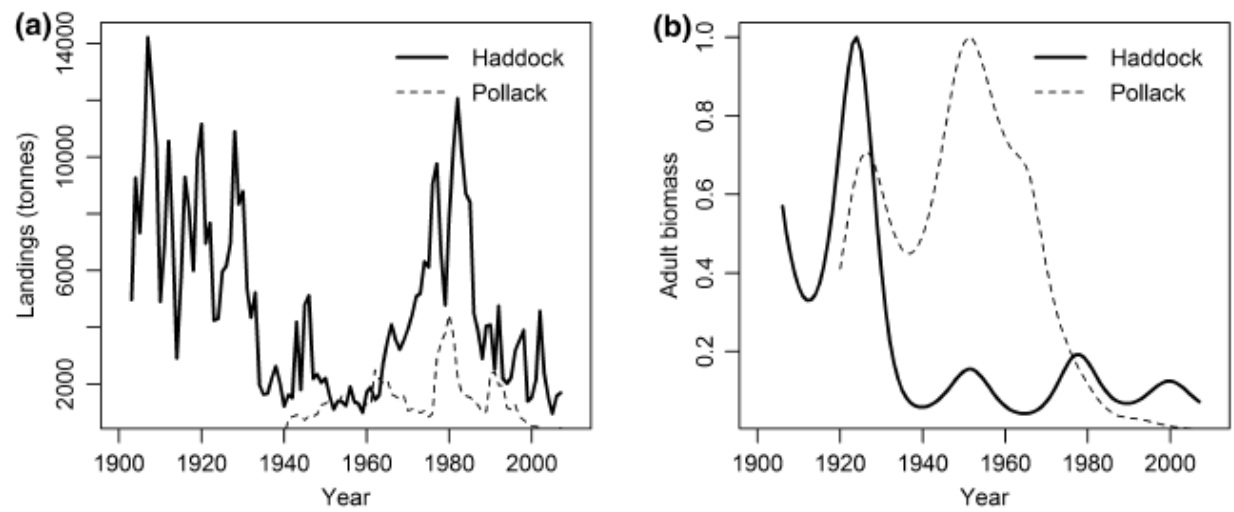

(c)

Pollack
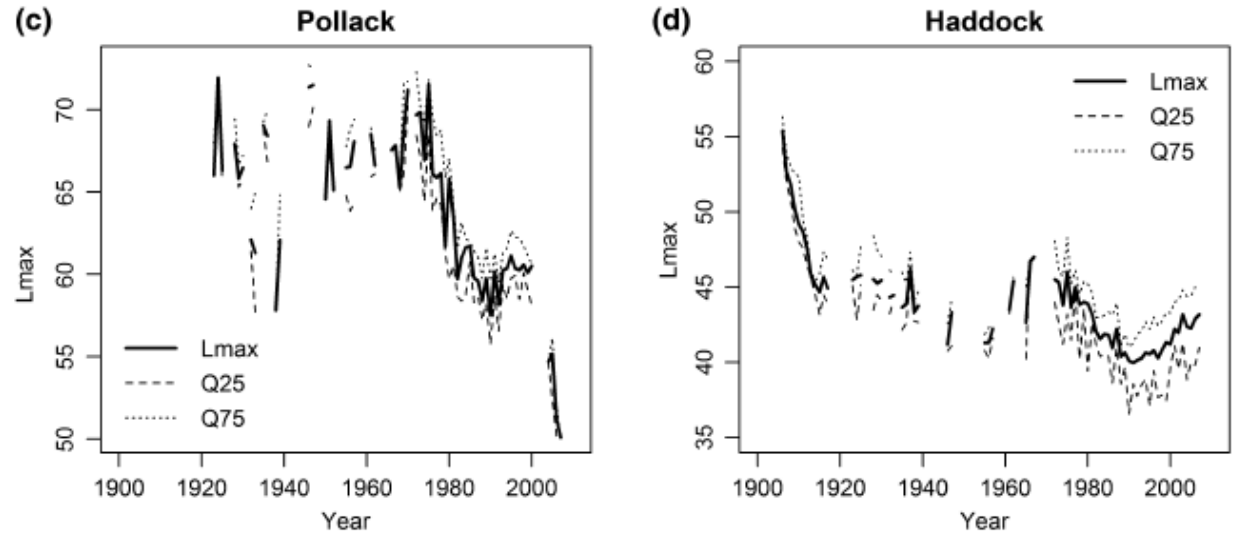

Source: Cardinale et al., 2012.

For the people around the Baltic Sea, on Greenland and the Faroe Islands, consumption of for instance, pilot whale, fatty fish and seabirds has become an apparent health risk due to storage of lipophilic pollutants in fatty tissues (e.g. Sørensen, Roto, \& Tunón, 2018). This shows that far distance pollution may threaten the local use of biological resources and consequently the local food security. The lion part of these pollutants is from more distant and heavily industrial countries of Western Europe. The problem of persistent organic pollutants has been addressed for several years in Arctic Council work, especially amongst the Invit, who in similarity to the Faroese, use a lot of game (wild marine animals and birds) as their food source. The Arctic Monitoring and Assessment Programme (AMAP, 2011), as well as the Inuit Circumpolar Council, have in campaigns in the villages in Nunavut demonstrated the need for safe foods and maintaining traditional practices.

Exploitation of coastal areas and displacement of small-scale fisheries by recreational fishing, as well as by offshore large-scale professional fishery, is problematic as job 
opportunities and livelihoods are being diminished in coastal regions. In the past, there were many households and small-scale fishers along the coast. Fishery was an essential basis for survival, both regarding the nutritional and economic value along the coasts. Moreover, fishing was seldom the sole occupation, but one of several economic activities within a household. Over the last decades, fishing practices have been specialized and reserved to a few professional fishers with consequences for subsistence fishing, which has almost disappeared as a phenomenon in coastal areas all over the Nordic countries.

\subsubsection{Energy security}

Energy is a provisioning NCP. Beside nuclear, hydroelectric and wind power, fossil resources are still vital to our economies and welfare. It is however, for many reasons of paramount importance, that the use of this NCP is reduced. It is crucial to mitigate the climatic consequences of exploiting fossil carbon reserves by eliminating $\mathrm{CO}_{2}$ emissions where possible. While the development of coastal wind power, wave and tidal energy can reduce dependence on fossil fuels, such exploitation, both on land and at sea, may significantly reduce the value of scenery as well as severely modify biodiversity and ecosystem function. Energy security is costly and reduced use of energy is one of the best options for securing another NCP. Furthermore, energy saving is often the most cost-efficient and feasible way of solving energy demands (e.g. Oikonomou et al., 2009). This is however depenent on whether the reduced energy consumption for one purpose is directed towards other forms of consumption or not. "Alternative" ways of producing energy are ingrained with difficult trade-offs and conflicts on environmental issues. In our Nordic studies, the location of offshore wind power in the Sound is an example of the competition for space. On the other hand, if wind farm construction only minimally disturbs marine life, they have the potential to function as marine protected areas because fishing activities are reduced in wind farm areas (Ashley et al., 2014).

\subsubsection{Livelihood security}

Livelihood security is of paramount importance and much concern at the political level.

The household livelihood security model puts emphasis on household actions, perceptions and choices (Fig. 12). Food is one among several priorities that people pursue. People are regularly required to balance food procurement against the satisfaction of other necessary material and intangible needs such as clean water, health facilities, educational opportunities, housing, time for community participation and social integration, as well as existential and spiritual needs (Maxwell \& Frankenberger, 1992).

The struggle for livelihood security in a broad sense is a significant driver behind the current trends in urbanisation and depopulation of remote areas in the Nordic countries. As livelihood security is perhaps increasingly decoupled from local NCP, economic and social constraints may lead to an abandonment of remote settlements. 


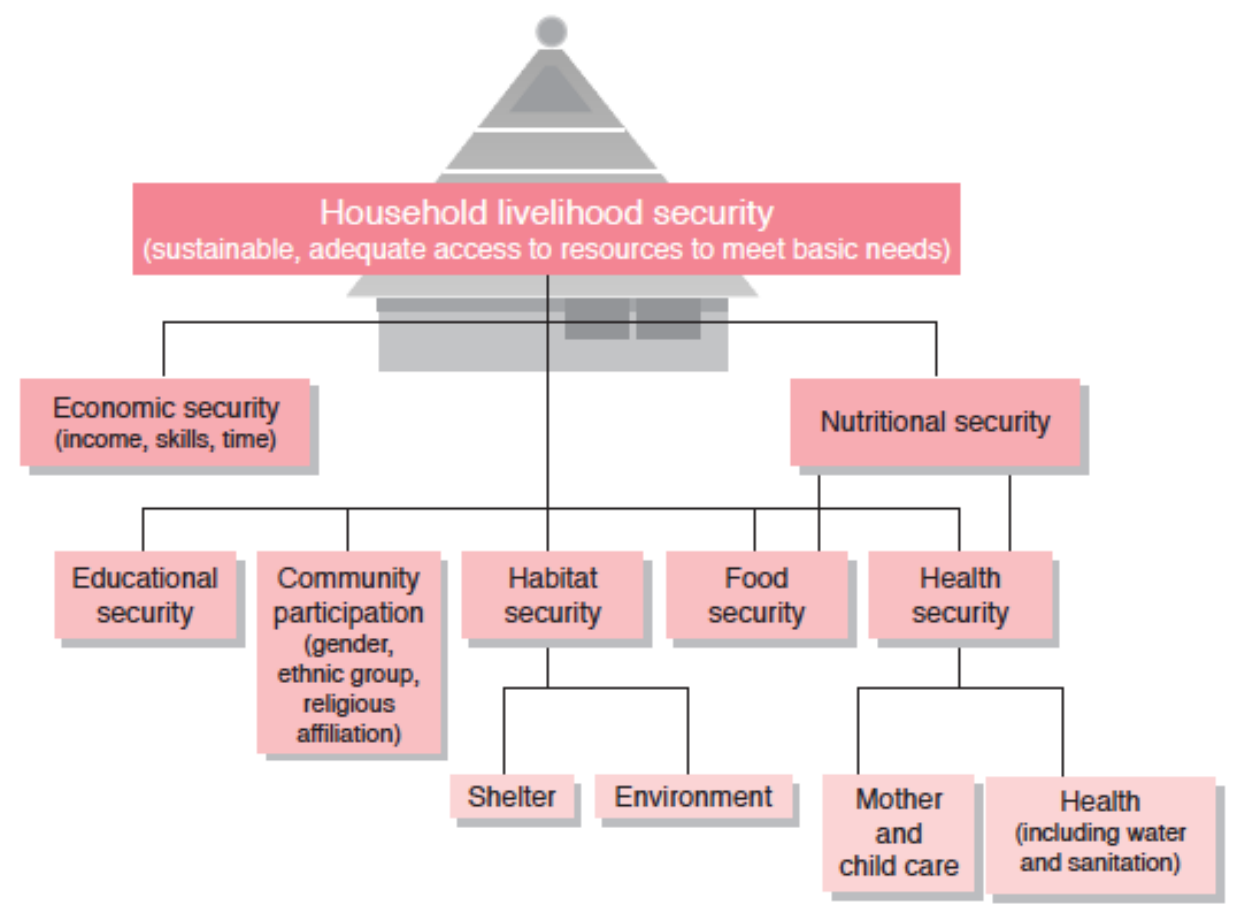

Source: Frankenberger \& McCaston, 1998.

Indigenous peoples and local communities with traditional lifestyles are heavily dependent on local biological resources, e.g. through fishing, hunting and harvesting of wild plants and berries, and are more likely to be affected by declining populations of important species (Gadgil et al., 1993; Tunón, 2004, 114-115). In modern societies such as those in Nordic countries, the concept of traditional lifestyles becomes a gradient from customary to a more modern small-scale use of local resources; yet, the good status of local ecosystem functioning and local biological resources is essential (c.f. Tunón (Ed.), 2018; Tunón, 2004, 114-115; Hernandéz-Morcillo et al., 2014). Rural people might be more or less dependent on the local biological resources for their subsistence, while the urban population to a large extent is detached from local dependencies and relies on the global market for everyday living. Consequently, the issue of dependence on local NCP can be seen as a question dividing rural and urban lifestyles. Even if the number of professional small-scale fishermen is going down, rural household fishing is still important since it opens an opportunity for comfortable living even below living wages (Tunón et al., 2015, and the ILK-process within this assessment, cp. Kvarnström \& Tunón, 2018). 


\subsubsection{Health security}

Health security may be seen as a part of household livelihood security (Fig. 12), such as contaminant-free food supply. In this Nordic coastal context, the issue of secure food often concerns the intake of toxic substances through seafood. Arguably, it also incorporates access for swimming, fishing and other forms recreational activities and cultural services. In this context, it is worth highlighting the importance of cultural contextualization to indigenous and local communities in their creation of a cultural and ethnic identity. This process is often formed in the context of customary use of local biodiversity or residing in the land. Albeit perceived as recreational activities, such activities are important carriers of tradition, culture and social health. Exploitation of the coast for housing and infrastructure may severely limit open-air recreational activities. For many people, the coastal environments are very crucial for their wellbeing and the privatisation of the most appreciated parts of the natural environment is both irreversible and ongoing. Housing and privatisation of coastal areas also pose a problem for reindeer herding (see e.g. the Kalix case study in Kvarnström \& Boström, 2018). Therefore, public access to coastal areas and the seashore should be very high on the political agenda.

Figure 13: The spread of pesticides such as DDT and its derivates had a severe impact on the reproduction of birds of prey

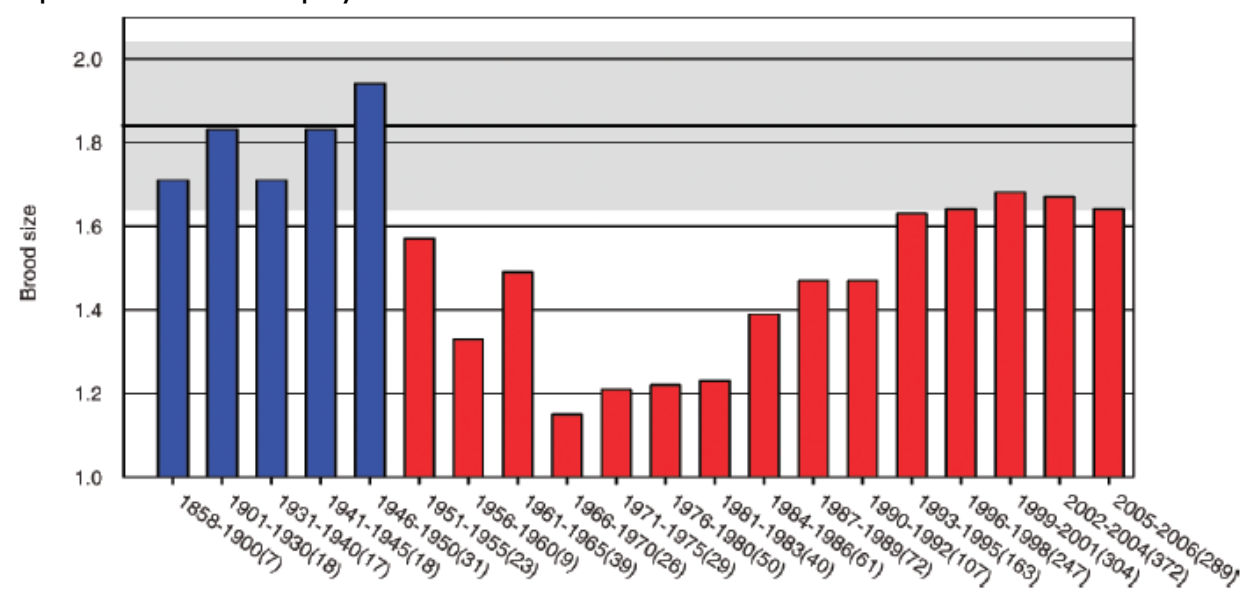

Note: Mean clutch size (number of juveniles per nest with nestlings) for white-tailed eagle (Haliaeetus albicilla) on the Swedish Baltic coast from the 19th century to 2008.

Source: Helander et al., 2008.

As mentioned in the previous section 2.2.1 on food security, marine commercial species exhibit varying levels of different harmful substances depending on, for instance, contamination source and trophic level. The substances may accumulate through the food-chain and be transferred to the people consuming them, which may lead to illness, impaired immune systems, hormone disorders and fertility problems, such as in whitetailed eagle (Haliaeetus albicilla) (Fig. 13). On the other hand, seafood is an important source of nutrients, including essential nutritional components such as fatty acids. The most successful way of minimising the risks without losing the health benefits is to limit 
consumption of fish species with a high methylmercury and other lipophilic pollutants content (EFSA, 2015).

Radioactivity has also been traced in sea plants as far away as in western Greenland. The Baltic Sea is considered one of the most radioactively contaminated seas in the world (Livingston \& Povinec, 2000). The largest source of radioactivity in fish, bladderwrack and aquatic organisms in the Baltic Sea is still the aftermath of the Chernobyl nuclear accident in 1986, more than three decades ago. Furthermore, in the Baltic region there are still remains left from the Soviet Union, including dumped chemicals and nuclear-powered lighthouses. The concentrations of radionuclides such as Cesium-137 in fish have declined considerably since the early 1990 and continue to decline. It is expected that adequately low concentrations of radioactive substances in biota and water may be achieved in all of the Baltic Sea by 2020 (HELCOM, 2017)

\subsubsection{Sustainability perspective}

Sustainable development has three interdependent and mutually reinforcing pillars economic development, social development and environmental protection (Long et al., 2015). Sustainability is considered to meet "the needs of the present without compromising the ability of future generations to meet their own needs" (cf. Brundtland, 1987). The political will is to ensure that environmental management, protection and conservation are integrated into sustainable development planning and management, by mainstreaming sustainability into society. For instance, Nordic parliamentarians suggest new laws in their focus on how to fight climate change. Many Nordic countries, including Åland, aim to mainstream sustainability into their daily life and the management of the environment and natural resources. However, this political ambition also has to be balanced with other aspects, e.g. economic growth, the spread of cities, the need for more energy, etc.

It is widely recognised, both politically and academically, that local communities with traditional lifestyles are more sensitive to changes in the natural world, due to their direct dependence on local living resources (e.g. the preamble of the UN Convention on Biological Diversity, 1992). For instance, a diminishing fish stock in a given area has a much stronger impact on local, small-scale artisanal fishers, than it has on larger, more industrial fishing vessels with the option to fish in other waters or follow the fish stock. A local farmer with grazing animals on islets in the Baltic archipelago often has more difficulties in finding alternative grazing than a large-scale farmer on the mainland with alternative grazing lands or means to buy additional fodder. Consequently, local fishers and hunters need to be more cautious in their fishing than visiting recreational anglers or hunting tourists, since they often are dependent only on local stocks and can follow population changes over time, while the latter quickly can choose to go to other places. There is a need for policy that maintains sustainable customary use in order to sustain the rural population in the future. Policies should build on the fact that the use of local biological resources goes beyond providing food and livelihoods, and constitutes an arena where cultural identity and inter-generational relationships are formed. 
On the other hand, people in rural communities involved in small-scale farming, fishing and other locally based economic activities, are often less dependent on open market relationships and monetary subsistence than urbanised sections of the population. Many times, it is the possibility to use several different biological resources that is the reason why local cultures have developed and survived in marginal areas. However, as this way of living is less dependent on monetary income, it could be endangered if challenged by competition from other users, changed regulations or decline of the target species. Urban people often have larger incomes and better possibilities to invest in properties - also in rural areas - and are therefore competing with the young rural population. Consequently, local users of biological resources are being substituted by seasonal visitors and rural areas are being deserted during large parts of the year. Furthermore, the customary use of local resources in indigenous and local communities is, to a large extent, the core of the lifestyle and a matter of quality of life.

\subsection{Identifying aspects of biodiversity and ecosystem services critical to social relationships, spirituality and cultural identity}

\subsubsection{Technological change}

Local economies built on the use of natural, often living, resources are fragile to technological development that might change the local biological composition or the cultural construction of the community. The number of people involved and employed in agriculture, forestry, fishing, hunting, mining, industry and so on, have inevitably become less and less numerous over a long time. On the one hand, by becoming more efficient and specialised, our society as a whole becomes prosperous. These changes result in reshaping of the social and cultural organisation in the local communities, which also involves changing the customary governance systems related to the use of local biological resources.

\subsubsection{A sense of place}

A technological transformation might lead to a loss of sense of place and context for local people. Factors important for maintaining biodiversity, cultural diversity and other NCP are therefore severely affected by the constant economic, social and technological changes that are sweeping through our societies (e.g. Kvarnström \& Tunón 2018). In the Kalix area of the Bothnian Bay, local fishers and reindeer herders emphasize that their quality of life, sense of place and deep connection with the land is intimately linked to their possibilities to continue traditional, customary practices of fishing and reindeer herding (Kvarnström \& Boström, 2018). In Northern Iceland, the local women interviewed describe the importance of leaving the nearby mountain areas without disturbance in order to respect and maintain their sacredness. They also talk about "the hidden people", the non-human entities and beings of these sacred mountains 
(Mustonen, Mustonen \& Oddsdottir, 2018; Mustonen et al., 2018). On the Faroe Islands, the local inhabitants describe that to feel Faroese, one has to be brought up on the islands, have adapted to them, and felt the influence of the rough and changeable nature, the unpredictability of the weather, the beauty of the local nature, the possibility to wander freely and continue customary use of biodiversity in a sustainable way (Sørensen, Roto \& Tunón, 2018). Similar statements and sentiments are found in most of the case studies in this assessment (Tunón (Ed.), 2018).

In some cases, it is possible to take advantage of the increasing recreational value of birds, seals, whales, etc., as an alternative or complementary way of creating a new livelihood for people in the countryside or small towns. Tourism is, however, connected with many side-effects that may result in profound societal change. The industry is also dependent on continued economic growth, along with a wealthy urban population creating the financial opportunity.

As social relationships, cultural identity and spirituality often are closely tied to traditional ways of living, local and customary economic activities are encouraged and supported in some areas. Encouraging examples include fishing of the vendace at Kalix in the Bothnian Bay, which has been successfully maintained as a local industry. Similarly, the traditional communal seining (pulling) net fishing tradition is still surviving in the Puruvesi area (Mustonen, 2018b), and so is the seal hunting of coastal fishers in Iceland, as well as the pilot whale hunt in the Faroe Islands (Mustonen et al., 2018; Sørensen, Roto \& Tunón, 2018).

For indigenous people, such as the Skolt Saami and other Saami peoples, recent studies have documented that the Saami languages, practices and dwelling on traditional territories combined provide a biocultural landscape. Suggestively, a "Saami ecosystem". It reflects customary habits and traditional land and water occupancies with cultural-spiritual links to the place, which form an inseparable whole that is more than the sum of its parts.

Subsidies given to agriculture and fishery may in many cases however, be rather counterproductive. For example, the natural resource (e.g. a fish stock) is depleted as the cost is lowered by subsidies given as a lifeline to commercial users (e.g. Sterner \& Svedäng, 2005). Subsidies to farming could be equally destructive. For instance, in the Quark area the practice of preparing naturally acid soils with dykes to support agriculture has led to discharges of acidic water that destroy fish stocks in rivers and inshore areas (Ilvessalo-Lax et al., 2018).

\subsubsection{Legislation, guidelines, administration of biodiversity}

Governance and rules for the management of biodiversity do not always meet the reality on the ground (see also Chapter 6). For example, local fishermen have good knowledge of when and where fishing should be carried out for various species. They often argue that they could protect different species in a more nuanced way, if only they could have some impact in governance.

Fishing and hunting in small local communities is regulated by external governance systems, making it hard for indigenous people to live as they once did. Several of the 
species that have been the basis of their livelihoods are no longer harvested due to strict regulations. Collaborative management and shared governance are emerging to address and alleviate this situation (e.g. Bryhn et al., 2017). However, due to the decline in abundance of many species, few options besides harvest restrictions are available.

\subsubsection{Traditional land use on the coast}

Land use has changed profoundly in most Nordic countries, affecting biodiversity and NCP to a very large extent (e.g. Cui et al., 2014). The large-scale transformation of the Swedish Baltic landscape has had severe effects on biodiversity and NCP, not least in coastal areas (Eriksson \& Cousins, 2014; Fredh et al.,2017; Kritzberg, 2017).

The traditional way of life in most coastal areas in the Nordic countries (excluding Greenland due to the climatological conditions for cultivation) have consisted of a mixture of activities with fishing, agriculture and animal husbandry at the core, with hunting and gathering on the side. In some areas, the conditions for agriculture have been very favourable, but most often the soils have been poor and fields have been small. Animal husbandry has had better potential. Grazing of domestic animals, mainly sheep or goats, has been a necessity for subsistence reasons. Along the coasts of the Baltic Sea, fisher-farmers have had their cattle, sheep and goats grazing on islands and islets. The animals have had to be regularly moved from island to island to provide enough fodder; a time-consuming activity. However, today this custom is very rare. In the Faroe Islands, sheep farming on semi-natural pastures is still an essential part of traditional everyday land use, both from a subsistence and social/ cultural point of view (Fig. 14). Historically, it was necessary to have sheep, hunt and fish to be able to make a living, but nowadays it is more of a supplement to the household economy, a social and cultural aspect and a widespread family tradition. The conditions for cultivation are not very favourable, as only some $4 \%$ of the terrestrial area is suitable for agriculture. The principal crops are hay, potatoes and rhubarbs (Sørensen, Roto, \& Tunón, 2018). 
Figure 14: Most of the Faroese landscape consists of open pastures that have been grazed for centuries by sheep

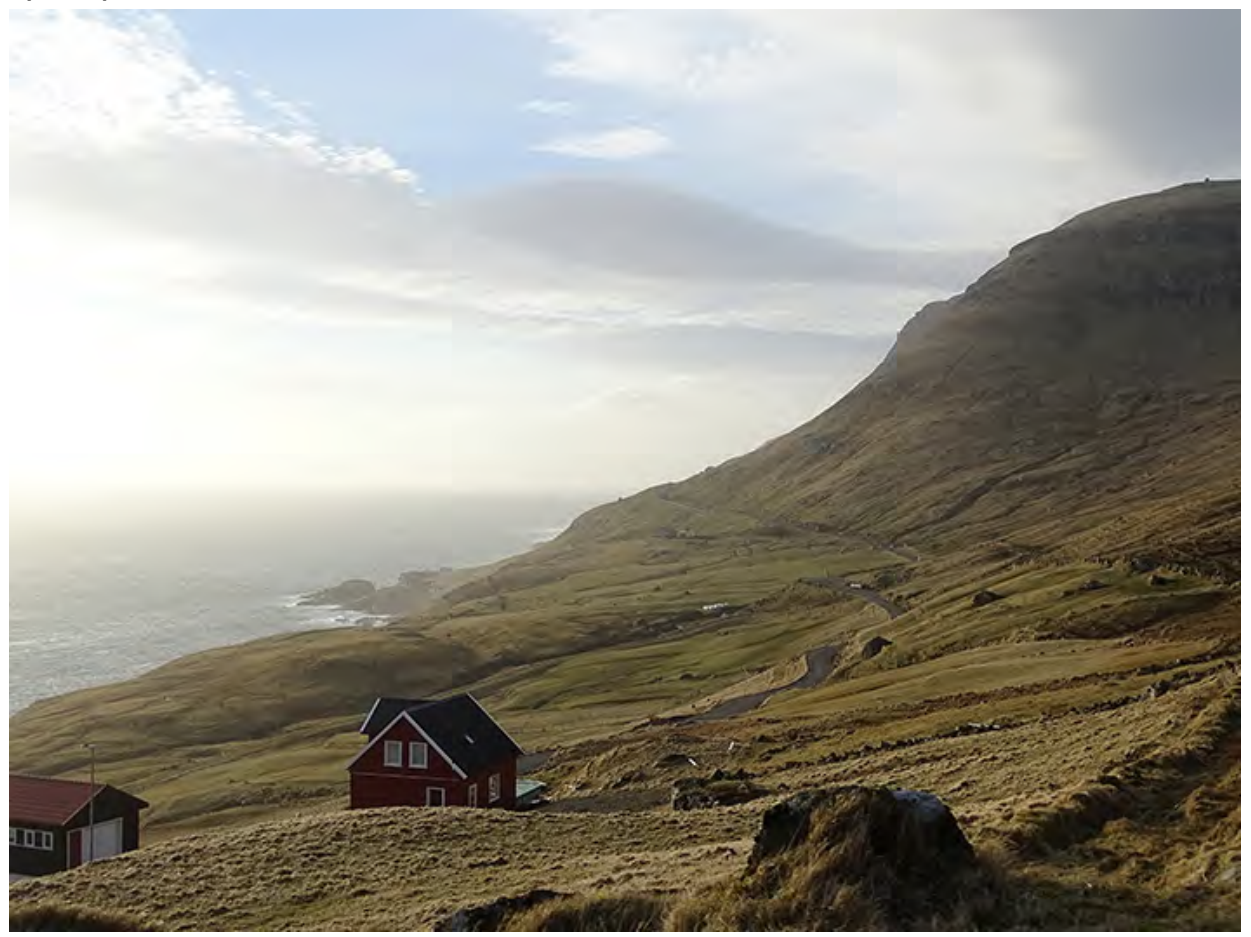

Source: Håkan Tunón, 2017.

There have also been intricate grazing systems on the coastal heaths in western Norway and Sweden. Grazing of sheep and cows in the summer has been alternated with the harvesting of heather (Calluna vulgaris) for winter fodder and bedding for the animals. When the heather has been too old, the grazing areas have been burned to stimulate the growth of grass and herbs. Today such areas are scarce and traditional management regimes are mainly performed for nature conservation. Grazing also used to be common on islands and isles in the Baltic Sea archipelago, as well as in other coastal areas in the Nordic region, but has during the last century become scarcer due to cost structure rationalisation. The result is more overgrowth and changes in biodiversity, where, for instance, less competitive plants are disappearing (Tunón et al., 2015).

Traditional land use has also undergone shifts. The archaeologist Noel Broadbent argues that the Baltic coastal seal hunt has its roots in a Saami siida territory use. Later in historical times when the Swedish/Finnish settlement expanded into the North Baltic coasts, the Saami switched or adapted to high mountain hunting, fishing and herder systems to alleviate resource pressure from the lost and occupied territories of the coast, but still retained the distinct siida governance. 


\subsubsection{Cultural values and biodiversity}

Landscapes and geological formations, as well as the biological diversityin a particular area, play a major role in shaping the cultural history of local communities and the local customary practices. Fishing methods, hunting techniques and other practices, which used to ensure the daily subsistence for the local community, have been developed in relation to the local landscape and its biodiversity. Together, this has contributed to what forms the local cultural heritage and identity, both materialistically and spiritually. The yearly cycle of physical and biological phenomena has developed a local calendar of customary practices, depending on resource availability and weather conditions. Consequently, there are cultural values closely linked to the harvest of particular biological resources (Tunón et al., 2015, and the ILK-process of this study, cp. Kvarnström \& Tunón, 2018). Today such events are subject to major social and cultural interest, but they are also essential for quality of life and for upholding a sense of identity in the local communities. They might be of importance for livelihoods but are in some cases of even higher symbolic value. These culturally important species may be significant locally and nationally, and in some some cases even internationally renowned. Below are some examples of species-specific social and cultural contexts.

\subsubsection{Culturally important species}

\section{Eel}

The eel (Anguilla anguilla) population span from northern Europe in to the Mediterranean and the Black Sea. It is a fish of some folkloristic importance in the Nordic countries, especially in southern Scandinavia. The fish is consumed all year round, but nowadays especially at Christmas. However, at the "eel coast" at Hanö Bay in eastern Scania in Southern Sweden, the traditional fishing and eating of eel has taken spectacular forms with "eel feasts" (ålagillen), where a variety of eel dishes are prepared and ceremonies take place during autumn. The eel culture in the area has been proposed as a cultural heritage to be listed nationally within the UNESCO Convention for the safeguarding of the intangible cultural heritage from 2003. Since 2007, a fishing license is required for eel fishing due to the endangered status of the European eel (Fig. 15). While current eel stock could sustain the cultural traditions in eastern Scania, the present eel fishing intensity as a whole is not sustainable (Svedäng \& Gipperth 2012). Although eel fishing occurs all over Europe, the Nordic impact on the eel stock is likely to be significant, as both Sweden and Denmark are two major European eel fishing nations (ICES 2016). Furthermore, the remaining eels in the Baltic might be one of the last more substantial living reserves. 
Figure 15: Eel (Anguilla anguilla) recruitment in Europe based on the ICES (WGEEL) recruitment index

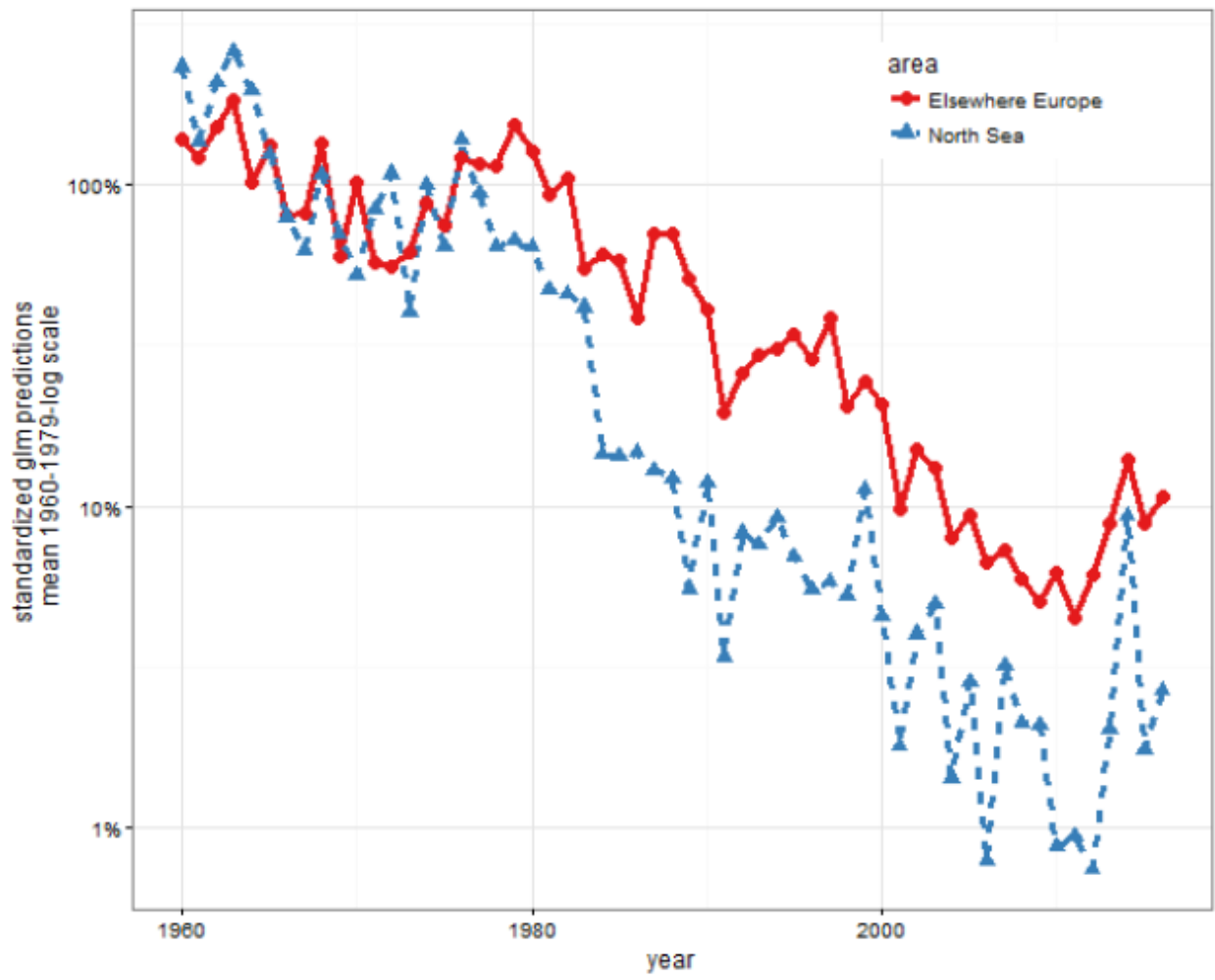

Note: It shows the geometric mean of estimated glass eel recruitment for the continental coasts bordering the North Sea and Elsewhere [in] Europe till year 2016. The model was fitted with 33 time-series comprising either pure glass eel or a mixture of glass eels and yellow eels and scaled to the 1960-1979 average. No time-series are available for glass eel in the Baltic area. Note the logarithmic scale on the $y$-axis.

Source: ICES, 2016.

\section{Vendace}

Vendace (Coregonus albula) is a small salmonid fish, whose roe is very esteemed and marketed as caviar (löjrom). Vendace is common in the brackish Bothnian Bay, where local roe fishery has existed for generations. The vendace roe from the Kalix archipelago, the "Kalix löjrom", has been harvested since the 1950 s and received a protected designation of origin (PDO) by the EU in 2010. The fishery takes place in late September and October. Kalix löjrom is often served at the Nobel Banquet and other distinguished events. Consequently, the local communities in the area are very proud of their fish and their product (Kvarnström \& Boström, 2018).

Vendace is also the iconic fish of the Puruvesi winter seiners on the large Saimaa Lake system. Also, a home to the freshwater seal and land-locked Atlantic Salmon, Puruvesi is a sea-like ecosystem housing a traditional fishing community. The vendace of Puruvesi has an EU Geographical Indicator for the traditional harvest, which is a sealfriendly and of particular biological quality. The traditional harvest with seining does not affect the seals negatively (no entanglement or by-catch issues). The clear water of 
Puruvesi, with visibility being very good, has affected the softer bone structure and high Vitamin D contents of the vendace, making them stand out compared toother stocks of the same species even on neighboring lakes. The oral culture of the Puruvesi winter seiners is currently under consideration for nomination as an intangible cultural heritage of UNESCO (Mustonen, 2018a).

\section{Eider}

Historically, spring hunting of migrating seabirds was common in the Nordic region. Today, due to the EU Species and Habitats Directive, most countries no longer have any hunting during spring. However, Åland has an exemption to hunt male seabirds in the spring, especially common eider (Somateria mollissima), and is still arguing for its continuation. Only adult males are shot during the hunting season, which occurs over a two-week period.

The hunt takes place when the mating season has ended and when the female is nesting. In the old fisher-farmer communities, spring seabird hunting was a matter of survival. Today the hunt, while no longer crucial for survival, is still an important part of life and culture. The spring hunt also gives the local communities incentives for conservation efforts beneficial to the seabird populations, e.g. predator control.

Another example of the relationship between man and common eiders is in the Vega archipelago in Norway. Due to the high value of eider down, the local people started to tend female eiders and protect them against predators at the nests in order to ensure a viable population. This relationship between the birds and the bird tenders is of a unique character, preserved as a socio-culturally significant UNESCO world heritage site. The down is still harvested and made into exclusive quilts sold all over the world. Unlike most down products, here it is possible to collect the down in an entirely non-destructive way (Hancke et al., 2018).

In recent years, the eider population in the Baltic Sea has declined (Ekroos et al., 2012). The decline has been related to high mortality of the newly hatched pulli (Fig. 16). The death of the young birds is due to deficiency of thiamin (vitamin $\mathrm{B} 1$ ), however the reason why this deficiency develops in a number of Baltic species, still remains unknown (Mörner et al., 2017). 
Figure 16: Herring gull (Larus argentatus) attack on an eider gathering at Vållholmen in the Blekinge archipelago (Sweden)

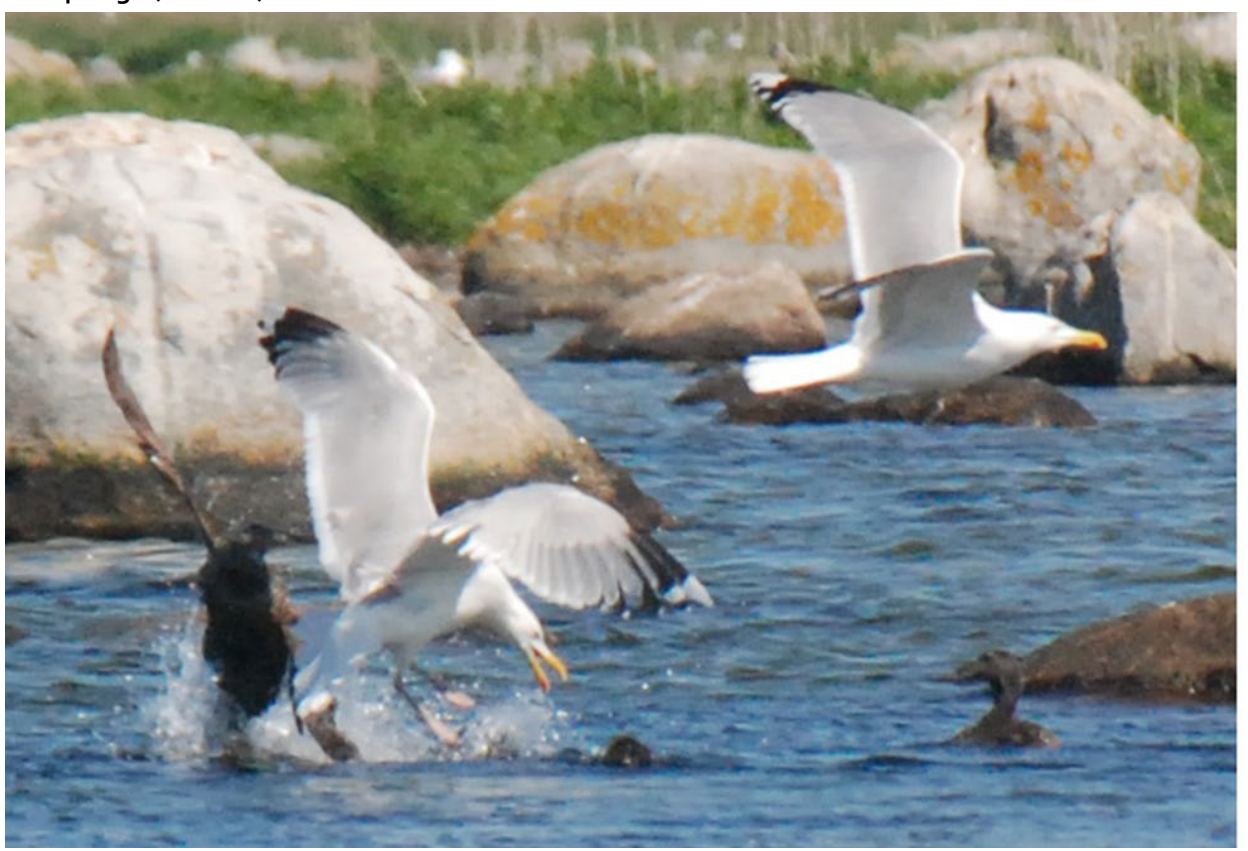

Note: Due to thiamin deficiency, leading to brain damage among other symptoms, the pulli neither dived nor ran away and were thus an easy prey to catch

Source: Mörner et al., 2017.

\section{Whale hunting}

Figure 17: Pilot whale hunting (Grindadráp) on the Faroe Islands, the traditional harvesting of longfinned pilot whales (Globicephala melas)

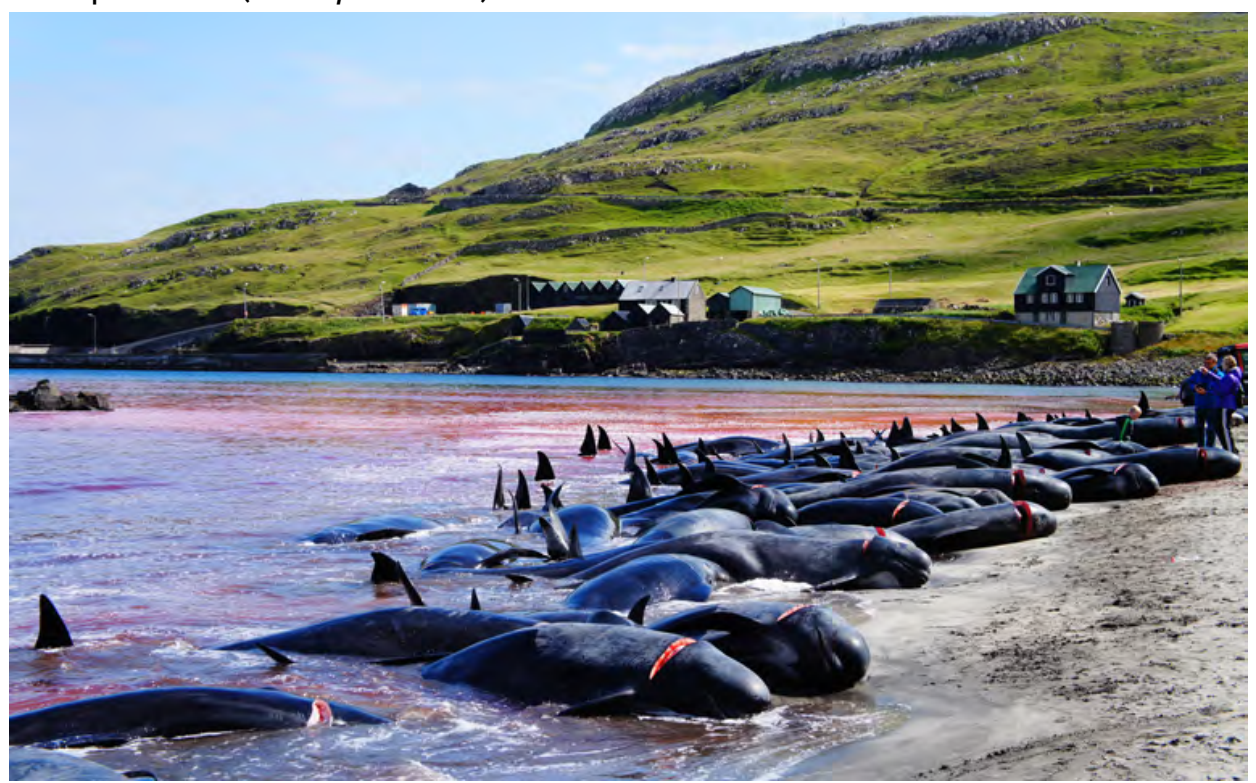

Source: Nazuna Nakao. 
Pilot whale hunting (Grindadráp) in the Faroe Islands (Fig. 17) is a thousand-year old tradition that takes place at irregular intervals. It involves the harvesting of long-finned pilot whales (Globicephala melas) and occasional dolphins. This traditional hunt is passive in the sense that the hunters wait until a shoal of whales is approaching. The whales are not actively seeked, but when spotted while carrying out fishing at sea and hunting conditions are favorable, a grindadráp is organized. It is an important social event for the local community and engages many of its inhabitants. Whale still constitutes a fair share of the meat consumption in the Faroe Islands, but problems with contamination of hazardous pollutants have led to discussions regarding local health issues (Sørensen, Roto \& Tunón, 2018).

\section{Cetacean and seal watching}

For many people, cetacean animals, i.e. whales and dolphins, are very attractive and in many places around the world, they can be seen in the wild. For instance, around twenty years ago, packs of killer whales (Orcinus orca) started feeding on herring during late autumn in Norwegian Tysfjord, which is easily accessed. Consequently, whalewatching tours were arranged and now more and more companies are offering their services. In Iceland, the former whale-hunting communities, e.g. Húsavík, have turned to whale watching instead. People tend to refer to an almost spiritual feeling when experiencing these large marine mammals. Furthermore, as seals have become more abundant over the last decades in the Baltic Sea, small companies along the Swedish coast have started seal safaris to give people an opportunity to view seals in the wild.

\subsection{Innovations and conflicts with biodiversity}

\subsubsection{Innovation}

\section{Wind parks}

Intensive planning and building of offshore wind parks is increasing along Nordic coastal areas. Construction activities should be avoided in critical recruitment areas for marine mammals and fish because these localities are sensitive to disturbance. Similarly, actions to reduce exposure to damaging noise levels should always be undertaken. To minimize impacts on migrating species, construction activities should not take place during biologically sensitive periods of the year. Avoiding harmful noise levels during spawning season should be prioritized due to the limited mobility of younger life stages.

One challenge for marine spatial planning is to assess the effects of trade-offs on a broader geographical scale. The potential harmful impacts of offshore wind parks can be minimized within the planning process, by avoiding crucial recruitment areas and by timing construction activities outside the main breeding seasons. Offshore wind farms can help preserve fish stocks and other marine life by restricting the access to some parts of the sea (Asley et al., 2014). For example, in regions where bottom-trawling has 
formerly been the dominant fishing method, some beneficial effects on local benthic species are often noticed following wind park construction (Lindeboom et al., 2011).

\section{Wave power}

The use of wave energy for electricity generation might expand in some areas in the region. However, today there are only a small number of experimental wave generator plants in operation and more research is needed to get some real conclusions about this kind of energy production. Effects on the environment have been suggested to mainly occur during the construction phase. Similar to windmill parks, the delimitation of some sea areas around ocean energy installation may function as de facto marine reserves (Gasparatos et al., 2017).

\subsubsection{Nature-based solutions}

Changes in land-use such as drainage, use of artificial fertilizers and grazing, may seriously affect the coastal environment. It is therefore of great importance to recirculate nutrient losses from land to coastal waters (e.g. Grant et al., 2007). "Green infrastructure", such as the restoration and construction of wetlands for nutrient retention purposes, are now rather wide-spread in Nordic countries (e.g. Hansson et al., 2005; Hoffmann \& BaattrupPedersen, 2007). Many times, if appropriately constructured, such created wetlands may also contribute to restoring former biodiversity. There is an increased interest in using some animal species as a means for decreasing the occurrence of heavy metals, hydrocarbons, nutrients and persistent organic pollutants, particularly in an aquatic environment. Recent examples include the harvest of fish to remove polychlorinated biphenyls (PCBs) from the Baltic (MacKenzie et al., 2004). Cultivation of blue mussels (Mytilus edulis) has been suggested as a means to remove nutrients in the Baltic Sea, as well as in the Kattegat and Skagerrak (Lindahl et al., 2005).

\subsubsection{Job market impacts}

All the case studies (Tunón (Ed.), 2018) and the ILK studies (Kvarnström \& Tunón, 2018) give a clear vision regarding the importance of NCP for the entire local society, including the job market. Even if it is not necessarily a question of traditional fishing and farming, many other contributions can be the basis for income. For example, naturebased tourism, recreational fishery, diving, hiking and so on, also deliver earnings that can be crucial to the survival of small societies with only small possibilities for other kinds of jobs. 


\subsection{Biocultural diversity}

Biocultural diversity describes the tie between the cultural and biological diversity. This link has become more acknowledged over the last decade following research showing that areas with higher cultural and language diversity often overlap with areas of greater biological diversity (e.g. Loh \& Harmon, 2005; Gorenflo et al., 2012).

One of the presumed reasons for this link is that indigenous cultures are considered to have developed more sustainable lifestyles through their high and direct dependency on local resources. It also assumes that they act as wise trustees of biodiversity. This concept brings a massive paradigm shift in biodiversity conservation strategies. Just a few decades ago, the most common strategy was still to exclude people from nature reserves to protect its biodiversity and habitats. Today, conservation strategies are starting to consider indigenous people as potential allies in the protection of biodiversity. There are examples of successful community conservation projects around the world that aim to empower people and enable them to continue to protect the environment (e.g. https://www.naturskyddsforeningen.se/nyheter/smaskaligt-fiske-starks-i-sydafrika).

These are commonplace in the Nordic countries, such as the Swedish Society for Nature Conservation, which is a charitable environmental organisation with the power to bring about change with almost a quarter of a million members.

Linguistic diversity is often used as an indicator of cultural diversity, which may in turn be linked to biodiversity. According to recent studies, the global decline of linguistic diversity (see below) is even faster than the decline of biological diversity. UNESCO and other organisations promote education in mother tongues and multilingualism. In Finland, Norway and Sweden, processes have been initiated to support and regenerate the Saami languages. Many Saami emphasize the importance of the Saami language in maintaining a close relationship with the land and its ecosystems. The organisation Terralingua supports "the investigation of the links between biological, cultural, and linguistic diversity, as well as the adoption of an integrated biocultural perspective on the perpetuation, maintenance and recovery of diversity on Earth" (http://www. http://sacredland.org/terralingua// accessed on 2018-04-12).

\subsubsection{Biological diversity}

Many studies suggest a close connection between biodiversity and the resilience of ecosystem function (Oliver et al., 2015). It has been suggested that lost biodiversity increases the spread of infectious diseases (Keesing et al., 2010) and new research points to $t$ thathe loss of biodiversity may be related to allergies and chronic inflammatory diseases in urban environments (Hanski et al. 2012). Indirectly, NCP contribute to health benefits through water purification, food and medicine production, and reduce the risk of negative health consequences of extreme weather events (Coutts \& Taylor, 2011). Ecosystem services do not include only biodiversity and life-sustaining systems, but also provide an excellent arena for health promotion and well-being (Maller et al., 2006). 


\subsubsection{Cultural and linguistic diversity}

The five Nordic countries and the three autonomous areas, Faroe Islands, Greenland and Åland, have a considerable shared history and substantial similarities, but also local differences in traditions and the use of biological diversity depending on geographical, climatological and ecological differences. The cultural differences may be based on nationality, but also on whether people belong to rural or urban populations or if they are farmers, fishers or other kinds of users directly dependent on biological resources. In the Nordic countries, there are main nationalities, minorities, e.g. immigrants and traditional inhabitants, and two indigenous groups, the Saami people in Sápmi in Northern Norway, Sweden, Finland and on the Kola Peninsula, and the Inuit on Greenland/Kalaallit Nunaat. To a large extent, ethnic and local culture plays an important role when it comes to the local customs, traditions and customary uses of biological resources.

In the Nordic countries, there national languages are Danish, Faroese, Icelandic, Norwegian, and Swedish (Germanic languages) and Finnish (Finno-Ugrian languages). Additional Finno-Ugrian languages are the Saami languages Inari, Lule, North, Pite, Skolt and South Saami, as well as Karelian and Olonetsian. Dalecarlian or Elfdalian, Gutnish, Low Saxon and South Jutish are minor Germanic languages. Romani (IndoEuropean language) and Yiddish are other minority languages. On Greenland the Inuit languages are East, West and North Greenlandic (Tunumiit oraasiat, Kalaallisut and Inuktun, respectively) (UNESCO Atlas of the World's Languages in Danger http://www.unesco.org/languages-atlas/; Tunón et al., 2015).

Apart from these languages, various dialects are spoken, as well as "professional" jargon within trades, which is developed from experience-based and trade-related knowledge shared by the peers. Such jargon is essential for carrying both culture and knowledge among the practitioners, as well as playing an important social role. Consequently, farmers, fishers, hunters, etc. each share common terminology and vocabulary with their peers that needs to be transferred from generation to generation as an important part and carrier of the knowledge system. A classic example is the richness of Saami nomenclature for snow and ice. In general, the more dependent local people are of a certain biological resource or climatological and ecological factor, the more diverse the nomenclature is that describes it. Consequently, fishers have a diverse vocabulary reflecting water conditions and over-/underwater topography, a particular fish species has different names in different age categories and seal hunters in the Gulf of Bothnia used a refined language to describe the ice conditions and the seals as such, etc. The local people also carry the cultural history of an area in the local place names that mirror past uses at specific sites or the historical biodiversity of the locality. 


\subsection{Multiple values of biodiversity and NCP}

\subsubsection{Strategies for valuation}

Depending on who is evaluating NCP, the result may differ quite considerably (Pascual et al., 2017). The valuation can vary due to changes in social or ecological conditions or perceptions, access to new information or because of worldviews or ideologies.

Policy decisions are needed to balance various options to sustain society's longterm need for functioning ecosystem services. Evaluation of the status and trends of ecosystem services helps to consider impacts of multiple decisions and the trade-offs between the different uses of the environment and NCP (Hattam et al., 2015). Economic valuation of NCP can help determine whether a project, a plan or a policy leads to socio-economic profitability or loss. Also, such analysis enables prioritizing between different measures, investigating conflicts of interest and facilitates balancing between various aspirations and goals. Valuation might be informative as a basis for land use or maritime spatial planning decisions, such as where and how to locate housing or coastal infrastructure and how these might affect NCP. Further, economic valuation provides a common currency to communicate the value of a threatened ecosystem service ("The cost of inaction") or the value of restoration projects that could improve the ability of ecosystems to generate benefits for the community. The valuation of NCP can also form the basis for decisions about a company's strategic focus, for example by preparing the business to consider future risks in the supply chain that could be associated with environmental impacts on the generation of natural resources for the NCP. Likewise, such information could support business operations to contribute positively to the generation of NCP for communities. Valuation of NCP can develop a basis for environmental accounts at municipal or national level. The Economics of Ecosystems and Biodiversity (TEEB) is a global initiative focused on "making nature's values visible". Its principal objective is to mainstream the values of biodiversity and ecosystem services into decision-making at all levels. This goal aims at supporting decision-makers to recognise the wide range of benefits provided by ecosystems and biodiversity, display their values in economic terms and, where adaptable, obtain those values in decision-making.

At the same time, it needs to be recognized that all NCP cannot be valued in monetary terms. Spiritual values, such as the sacredness of a mountain, are priceless to the holders of those values, and it is important to develop language and practices in strategies and policymaking that fully incorporate these values.

\subsubsection{International target-setting}

Global sustainability policies aim to ensure human well-being and the sustainable use of our planet's resources, whether via sustainable development of society or via biodiversity conservation (Geijzendorffer et al., 2017). A new set of post-2015 development goals, the United Nations Sustainable Development Goals (SDGs), focus on poverty eradication and sustainable development. Unsustainable resource use is 
causing biodiversity loss and natural resource degradation, with the poor being disproportionately affected.

Such concerns are also one of the foundations of the Strategic Plan for Biodiversity of the Convention on Biological Diversity (CBD) (Lucas et al., 2015). The Strategic plan expresses a 2050 vision on biodiversity, accompanied by five Strategic Goals and 20 targets of the Conventional of Biological Diversity (CBD), the so-called Aichi Biodiversity Targets (https://www.cbd.int/sp/targets/ and e.g. Lucas et al. 2015 and the references therein). Integrating these agendas in to Nordic policy is vital because biodiversity and ecosystem services are essential for human well-being and poverty eradication.

Some of the Aichi targets, such as 1, 2, 6, 14, 15, 16, 18 and 19 (see Lucas et al. 2015), reflect essential aspects of the Nordic coastal environment. In the Nordic countries, many aspects of monitoring, conservation and recovery of biodiversity are linked to general agreements, such as the EU directives and regional organisations such as HELCOM and the Nordic Council. Stakeholder participation is needed, also because their needs and their knowledge are essential to this process.

\subsection{Knowledge gaps}

- Monitor all types of NCP or ecosystem services, i.e. provisioning, regulating, cultural and maintenance, as well as supporting services. Critical review of existing indicators is needed, specifically in tmeros of tracking the development of biodiversity and NCP (Aichi Target 19);

- Only by actively analysing data and creating syntheses, is it possible to understand changes in the ecosystem that may harm biodiversity and NCP if left unattended.

\subsection{Policy Recommendations}

- Develop transparent and documented political strategies regarding biodiversity and nature's contributions to people (NCP) to achieve food, energy, health and livelihood security in Nordic coastal areas (relates to Aichi Targets 6 and 14);

- Develop and improve existent indicators on biodiversity and NCP in the coastal zone for provisioning, regulating and maintenance, as well as cultural and supporting services;

- Indigenous and local knowledge may give information to managers and scientists. Thus, researchers and managers should develop a dialogue and mutual exchange of data and information (relates to Aichi Targets 18 and 17);

- The current valuation of NCP and ecosystem services represents values in a broad sense. Non-monetary valuation methods need to be included in management strategies and policy implementation; 
- Stakeholders should be involved in documenting and identifying key socioecological areas, biodiversity hotspots and sacred sites (while applying Free and Prior Informed Consent (FPIC).

\subsection{Acronyms}

- $\quad$ CBD - UN Convention on Biological Diversity

- EFSA - European Food Safety Authority

- GDP-Gross Domestic Product

- NCP - Nature's Contributions to People

- SDGs - Sustainable Development Goals. 


\subsection{References}

AMAP (Arctic Monitoring and Assessment Programme). (2011). AMAP Assessment 2011: Mercury in the Arctic. Oslo: AMAP.

Ashley, M. C., Mangi, S. C., \& Rodwell L. D. (2014). The potential of offshore windfarms to act as marine protected areas-A systematic review of current evidence. Marine Policy, 45, 301-309.

Böhnke-Henrichs, A., Baulcomb, C., Koss, R., Hussain, S. S., \& de Groot, R. S. (2013). Typology and indicators of ecosystem services for marine spatial planning and management. Journal of Environmental Management, 130, 135-45. doi: 10.1016/j.jenvman.2013.08.027.

Bridgewater, P. (2017). The intergovernmental platform for biodiversity and ecosystem services (IPBES) - a role for heritage? International Journal of Heritage Studies, 23, 65-73.

Brundtland commission, (1987). Our common future. the world commission on environment and development, 1987.

Bryhn, A., Lundström, K., Johansson, A., Ragnarsson Stabo, H., \& Svedäng, H. (2017). A continuous involvement of stakeholders promotes the ecosystem approach to fisheries in the 8-fjords area on the Swedish west coast. ICES Journal of Marine Science, 74, 431-442. doi:10.1093/icesjms/fsw217.

Cardinale, M., Svedäng, H., Bartolino, V., Maiorano, L., Casini, M., \& Linderholm, H. W. (2012). Spatial and temporal depletion of haddock and pollack during the last century in the KattegatSkagerrak. Journal of Applied Ichthyology, 28, 1-9. doi: 10.1111/j.1439-0426.2012.01937.x

Chan, K. M. A., Balvanerab, P., Benessaiahc, K., Chapmana, M. et al. (2016). Opinion: Why protect nature? Rethinking values and the environment. Proceedings of the national academy of Sciences 113, 1462-1465. doi: 10.1073/pnas.1525002113

Costanza, R., Kubiszewski, I., Giovannini, E., Lovins, H., et al. (2014). Time to leave GDP behind. Nature, 505, 283-285.

Coutts, C. \& Taylor, C. (2011). Putting the capital "E" environment into ecological models of health. Journal of Environmental Health, 74, 26-29.

Cui, Q.Y., Gaillard, M.-J. Lemdahl, G., Sugita, S., Greisman, A., Jacobson, G.L. \& Olsson, F. (2013). The role of tree composition in Holocene fire history of the hemiboreal and southern boreal zones of southern Sweden, as revealed by the application of the landscape reconstruction algorithm: implications for biodiversity and climate-change issues. The Holocene, 23, 747-1763.

Czajkowski, M., Ahtiainen, H., Artell, J., Budziński, W., et al. (2015). Valuing the commons: An international study on the recreational benefits of the Baltic Sea. Journal of Environmental Management, 156, 209-217.

Diaz et al. (2015): The IPBES Conceptual framework-connecting nature and people http://www.ipbes.net/sites/default/files/downloads/pdf/Diaz_et_al._2015_IPBESConceptualFr amework.pdf

Dragesund, O., Johannessen, A. \& Ulltang, Ø. (1997). Variation in migration and abundance of Norwegian spring spawning herring (Clupea harengus L.). Sarsia, 82, 97-105.

Duraiappah, A., \&, Muñoz, P. (2012). Inclusive wealth: a tool for the United Nations. Environment and Development Economics, 17, 362-367.

EFSA 2015. Statement on the benefits of fish/seafood consumption compared to the risks of methylmercury in fish/seafood. EFSA Journal, 13, 3982.

Ekroos, J., Fox, A.D., Christensen, T.K., Petersen, I.K., et al. (2012). Declines amongst breeding Eider Somateria mollissima numbers in the Baltic/Wadden Sea flyway. Ornis Fennica, 89, 81-90.

Eriksson, O. \& Cousins, S.A.O. (2014). Historical Landscape Perspectives on Grasslands in Sweden and the Baltic Region. Land, 3, 300-321.

EU 511/2014. Regulation (EU) No 511/2014 of the European Parliament and of the Council of 16 April 2014 on compliance measures for users from the Nagoya Protocol on Access to Genetic Resources and the Fair and Equitable Sharing of Benefits Arising from their Utilization in the Union. 
Eurostat (2017) http://ec.europa.eu/eurostat/publications/all-publications

FAO. 2002. The State of Food Insecurity in the World 2001. Rome.

http://www.fao.org/docrep/005/y4671e/y4671eo6.htm

Frankenberger, T.R. \& McCaston, M.K. (1998). The household livelihood security concept. p. 3033. FAO.

Fredh, D., Mazier, F., Bragée, P., Lagerås, P., Rundgren M., Hammarlund, D., \& Broström, A. (2017). The effect of local land-use on floristic diversity during the past 1000 years in southern Sweden. The Holocene, 27, 694-711.

Gadgil, M., Berges, F. \& Folke, C. (1993). Indigenous Knowledge for Biodiversity Conservation. Ambio, 22, 151-156.

Gasparatos, A., Doll, C.N.H., Esteban, M., Ahmed, A. \& Olang, T.A. (2017). Renewable energy and biodiversity: implications for transitioning to a Green Economy. Renewable and Sustainable Energy Reviews, 70, 161-184.

Geijzendorffer, I.R. Cohen-Shacham, E., Cord, A.F., Cramer, W., Guerra, C. \& Martín-López, B. (2017). Ecosystem services in global sustainability policies. Environmental Science \& Policy, 74: 40-48.

Grant, J., Bugden, G., Horne, E., Archambault, M.-C. \& Carreau, M. (2007). Remote sensing of particle depletion by coastal suspension-feeders. Canadian Journal of Fisheries and Aquatic Sciences, 64, 387-390

Gorenflo, L.J., Romaine, S., Mittermeier, R.A. \& Walker-Painemilla, K. (2012). Co-occurrence of linguistic and biological diversity in biodiversity hotspots and high biodiversity wilderness areas. PNAS, 109, 8032-8037.

Gundersen, H., Bryan, T., Chen, W., May, F.E., et al. (2016) Ecosystem services in the coastal zone of the Nordic countries. TemaNord report 2016:552 https://norden.divaportal.org/smash/get/diva2:1067839/FULLTEXT01.pdf

Hancke, K., Gundersen, H., Magnussen, K., Postmyr, E., Andersen, G. S., Jacobsen, K. O., \& Tunón, H. (2018). Helgeland. An Atlantic Archipelago (pp. 171-200). In H. Tunón (Ed.). Nordic IPBES-like Assessment of Biodiversity and Ecosystem Services in Coastal Ecosystems. Case Areas. TemaNord 2018:532 Copenhagen: Nordic Council of Ministers.

Hanski, I. von Hertzen, L., Fyhrquist, N. Koskinen, K. et al., (2012). Environmental biodiversity, human microbiota, and allergy are interrelated. PNAS, 109, 8334-8339.

Hansson, L.-A., Brönmark, C., Nilsson, P. \& K. Åbjörnsson (2005). Conflicting demands on wetland ecosystem services: nutrient retention, biodiversity or both? Freshwater Biology, 50 705-714.

Haines-Young, R. \& Potschin, M. (2010). The links between biodiversity, ecosystem services and human well-being. British Ecological Society.

Hasler, B., Ahtiainen, H., Hasselström, L., Heiskanen, A.-S., Soutukorva, Å. \& Martinsen L. (2016). Marine ecosystem services in Nordic marine waters and the Baltic Sea-possibilities for valuation. TemaNord 2016:501. Nordic Council of Ministers.

http://dx.doi.org/10.6027/TN2016-501.

Hattam, C., Atkins, J.P., Beaumont, N., Börger, T., Böhnke-Henrichs, A., et al. (2015). Marine ecosystem services: linking indicators to their classification. Ecological Indicators, 49, 61-75.

HELCOM (2017): First version of the 'State of the Baltic Sea' report - June 2017 - to be updated in 2018. Available at: http://stateofthebalticsea.helcom.fi

Hernández-Morcillo, M., Hoberg, J., Oteros-Rozas, E., Plieninger, T., Gómez-Baggethun, E., \& Reyes-García, V. (2014). Traditional Ecological Knowledge in Europe: Status Quo and Insights for the Environmental Policy Agenda. Environment: Science and Policy for Sustainable Development, 56, 3-17. doi:10.1080/00139157.2014.861673

Helander, B., Bignert, A., \& Asplund, L. (2008). Using Raptors as Environmental Sentinels: Monitoring the White-tailed Sea Eagle Haliaeetus albicilla in Sweden. Ambio, 37, 425-431.

Hoffmann, C.C. \& Baattrup-Pedersen, A. (2007). Re-establishing freshwater wetlands in Denmark. Ecological Engineering, 30, 157-166.

ICES (2016). EIFAAC/ICES/GFCM WGEEL Report 2016. www.ices.dk 
ICES (2017). ICES WGBFAS Report 2017. Cod in the Baltic. www.ices.dk

IPBES (2017). 7 February 2017. Update on the classification of nature's contributions to people by the Intergovernmental Science-Policy Platform on Biodiversity and Ecosystem Services. Report of the Executive Secretary on the implementation of the work programme for the period 2014-2018.

Keesing, F., Belden, L.K., Daszak, P., Dobson, A. et al., (2010). Impacts of biodiversity on the emergence and transmission of infectious diseases. Nature, 468, 647-652.

Kritzberg, E.S., (2017). Centennial-long trends of lake browning show major effect of afforestation. Limnology and Oceanography Letters, 2, 105-112.

Kubiszewski, I., Costanza, R., Franco, C., Lawn, P., Talberth, J., Jackson, T. \& Aylmer C. (2013). Beyond GDP Measuring and achieving global genuine progress. Ecological Economics, 93, 57-68.

Kvarnström, M. \& Boström, J. (2018). Kalix archipelago (pp. 29-6o). In H. Tunón (Ed.). Nordic IPBES-like Assessment of Biodiversity and Ecosystem Services in Coastal Ecosystems. Case Areas. TemaNord 2018:532 Copenhagen: Nordic Council of Ministers.

Kvarnström, M. \& Tunón, H. (2018). Folklig kunskap i kust och skärgård. Supporting material regarding Indigenous and Local Knowledge in a Nordic IPBES-like assessment. Uppsala: Swedish Biodiversity Centre.

Lindahl, O., Hart, R., Hernroth, B., Kollberg, S., Loo, L-O., Olrog, L., Rehnstam-Holm, A.S., Svensson, J., Svensson, S. \& Syversen, U. (2005). Improving marine water quality by mussel farming: a profitable solution for Swedish society. Ambio, 34,131-138.

Lindeboom, H.J., Kouwenhoven, H.J., Bergman, M.J.N., Bouma, S., et al. (2011). Short-term ecological effects of an offshore wind farm in the Dutch coastal zone; a compilation. Environmental Research Letters. 6035101.

Livingston, H. D. \& Povinec, P. P. (2000). Anthropogenic marine radioactivity. Ocean \& Coastal Management., 43, 689-712

Loh, J. \& Harmon, D. (2005). A global index of biocultural diversity. Ecological Indicators, 5, 231-241.

Long, R. D., Charles, A. \& Stephenson, R. L., (2015). Key principles of marine ecosystem-based management. Marine Policy 57, 53-60.

Lucas, P., Kok, M. T. J., Nilsson, M., \& Alkemade, R. (2015). Integrating Biodiversity and Ecosystem Services in the Post-2015 Development Agenda: Goal Structure, Target Areas and Means of Implementation. Sustainability, 6, 193-216.

Lusher, A. L., Tirelli, V., O'Connor, I., \& Officer, R. (2015). Microplastics in Arctic polar waters: the first reported values of particles in surface and sub-surface samples. Scientific Reports 5 , 14947; doi: 10.1038/srep14947.

Mackenzie, B. R., Almesjö, L., \& Hansson, S. (2004). Fish, fishing, and pollutant reduction in the Baltic Sea. Environmental Science \& Technology, 38, 1970-1976.

Maller, C. \& Townsend, M. (2006). Children's mental health and wellbeing and hands-on contact with nature, International journal of learning, 12, 359-372.

Maxwell, S. \& Frankenberger, T. (Eds). (1992). Household food security: concepts, indicators, and measurements: a technical review. New York, NY, USA and Rome, UNICEF and IFAD.

Maes, J. et al. (2013). Mapping and Assessment of Ecosystems and their Services. An analytical framework for ecosystem assessments under action 5 of the EU biodiversity strategy to 2020. Luxembourg: Publications office of the European Union.

Maes, et al. (2014). Indicators for mapping ecosystem services - 2nd MAES Working Paper. European Union, doi: 10.2779/75203.

MEA (Millennium Ecosystem Assessment) (2005). Ecosystems and Human Well-Being: Current State and Trends. Island Press, Washington DC.

Moksnes, P.-O., Gullstrom, M., Tryman, K. \& Baden, S. (2008). Trophic cascades in a temperate seagrass community. Oikos, $117,763-777$. 
Mustonen, T. (2015). Ice Fishing Cultures of North Karelia. Case of Winter Seiners of Puruvesi. In Barucha, Zareen, Pretty, Jules and Böhm, Steffen. Ecocultures: Blueprints for Sustainable Communities. London: Routledge, 2015. pp. 44-61 ISBN: 978-0-415-81282-5

Mustonen, T. (2018b). Puruvesi (pp. 99-110). In H. Tunón (Ed.). Nordic IPBES-like Assessment of Biodiversity and Ecosystem Services in Coastal Ecosystems. Case Areas. TemaNord 2018:532 Copenhagen: Nordic Council of Ministers.

Mustonen, T., Mustonen, K., \& Oddsdottir, E. (2018a). Gendered Landscapes of Northern Icelandic Coasts and Rural Areas (pp. 249-290). In H. Tunón (Ed.). Nordic IPBES-like Assessment of Biodiversity and Ecosystem Services in Coastal Ecosystems. Case Areas. TemaNord 2018:532 Copenhagen: Nordic Council of Ministers.

Mustonen, T., Hjálmsdóttir, A., Arnarsdóttir, B. R., Oddsdóttir, E. E., Ásmundsson, J., \& Gudrúnardóttir, L. B. (2018a). "We're not the enemies of the seal": Seal hunters of Iceland (pp. 264-290). In H. Tunón (Ed.). Nordic IPBES-like Assessment of Biodiversity and Ecosystem Services in Coastal Ecosystems. Case Areas. TemaNord 2018:532 Copenhagen: Nordic Council of Ministers.

Mörner T., Hansson, T., Carlsson, L., Berg, A-L., Ruiz Muñoz, Y., Gustavsson, H., Mattsson, R. \& Balk, L. (2017). Thiamine deficiency impairs common eider (Somateria mollissima) reproduction in the field. Scientific Report, 7, 14451.

Oikonomou, V., Becchis, F., Steg, L. \& Russolillo, D. (2009). Energy saving and energy efficiency concepts for policy making. Energy Policy, 37, 4787-96.

Oliver, T.H., Heard, M.S., Isaac, N.J.B., Roy, D.B., Procter, D., et al. (2015). Biodiversity and resilience of ecosystem functions. Trends in Ecology and Evolution, 30, 673-684.

Pascual, U., Balvanera, P., Díaz, S., Pataki, G., Roth, E., et al., (2017). Valuing nature's contributions to people: the IPBES approach. Current Opinion in Environmental Sustainability, 26, 7-16.

Sheehan, M.C., Burke T.A., Navas-Acien, A., Breysse, P., N, McGready, J \& Fox, M.A. (2014). Global methylmercury exposure from seafood consumption and risk of developmental neurotoxicity: a systematic review. Bulletin of the World Health Organization, 92, 254-269.

Sterner, T. \& Svedäng, H. (2005). A net loss. Policy instruments for commercial fishing with focus on cod in Sweden. Ambio, 34, 84-90.

Svedäng, H. (2003). The inshore demersal fish community on the Swedish Skagerrak coast: regulation by recruitment from offshore sources. ICES Journal of Marine Science, 60, 23-31.

Svedäng, H. \& Bardon, G. (2003). Spatial and temporal aspects of the decline in cod (Gadus morhua L.) abundance in the Kattegat and eastern Skagerrak. ICES Journal of Marine Science, $60,32-37$.

Svedäng, H. \& Gipperth, L. (2012). Will regionalisation improve fisheries management in EU? An analysis of the Swedish eel management plan reflects difficulties. Marine Policy, 36, 801808.

Svedäng, H. \& Hornborg, S. (2017). Historic changes in length distributions of three Baltic cod (Gadus morhua) stocks: Evidence of growth retardation. Ecology \& Evolution, 7, 6089-6102. https://doi.org/10.1002/ece3.3173

Sørensen, J., Roto, J., \& Tunón, H. (2018). Faroe Islands (pp. 205-225). In H. Tunón (Ed.). Nordic IPBES-like Assessment of Biodiversity and Ecosystem Services in Coastal Ecosystems. Case Areas. TemaNord 2018:532 Copenhagen: Nordic Council of Ministers.

Trevail, A.M., Gabrielsen, G.W., Kühn, S. \& Van Franeker, J.A. (2015). Elevated levels of ingested plastic in a high Arctic seabird, the northern fulmar (Fulmarus glacialis). Polar Biology, 38, 975-981.

Tunón, H. (2004). Traditionell kunskap och lokalsamhällen: artikel 8j i Sverige. Uppsala: Centrum för biologisk mångfald.

Tunón, H., Kvarnström, M., \& Malmer, P. (2015). Report from the project: Indigenous and Local Knowledge in a Scoping Study for a Nordic IPBES Assessment. Uppsala: CBM.

Tunón, H. (Ed.). (2018). Nordic IPBES-like Assessment of Biodiversity and Ecosystem Services in Coastal Ecosystems. Case areas. TemaNord 2018: Copenhagen: Nordic Council of Ministers. 
UN Convention on Biological Diversity 1992. ( www.cbd.int)

UNEP (2006). Marine and coastal ecosystems and human well-being: A synthesis report based on the findings of the Millennium Ecosystem Assessment. UNEP. 76 pp. 
Biodiversity and ecosystem services in Nordic coastal ecosystems: an IPBES-like assessment. Volume 1. The general overview

Belgrano, A

Clausen, $\mathrm{P}$

Ejdung, G

Gamfeldt, L

Show others and affiliations

Responsible organisation

Nordic Council of Ministers, Nordic Council of Ministers Secretariat

2018 (English)

Book (Other academic)

\section{Abstract [en]}

This report describes the status and trends of biodiversity and ecosystem services in the Nordic region, the drivers and pressures affecting them, interactions and effects on people and society, and options for governance. The main report consists of two volumes. Volume 1 The general overview (this report) and Volume 2 The geographical case studies. This study has been inspired by the Intergovernmental Science-Policy Platform on Biodiversity and Ecosystems Services (IPBES). It departs from case studies (Volume 2, the geographical case studies) from ten geographical areas in the Nordic countries (Denmark, Finland, Iceland, Norway, Sweden) and the autonomous areas of Faroe Islands, Greenland, and Aland. The aim was to describe status and trends of biodiversity and ecosystem services in the Nordic region, including the drivers and pressures affecting these ecosystems, the effects on people and society and options for governance. The Nordic study is structured as closely as possible to the framework for the regional assessments currently being finalized within IPBES. The report highlights environmental differences and similarities in the Nordic coastal areas, like the inhabitants' relation to nature and the environment as well as similarities in social and policy instruments between the Nordic countries. This study provides background material for decision-making and it is shown that Nordic cooperation is of great importance for sustainable coastal management and should be strengthened in future work.

Place, publisher, year, edition, pages

Copenhagen: Nordisk Ministerråd, 2018. , p. 200

Series

TemaNord, ISSN 0908-6692; 2018:536

National Category

Environmental Management

Research subject

Animal life; Environment; Climate; Marine environment; Economy; Fisheries; Food; Welfare; Arctic; Barents Region; Baltic Sea Region; European Union; The Baltic Region

\section{Identifiers}

URN: urn:nbn:se:norden:org:diva-5272

DOI: $10.6027 /$ TN2018-536

ISBN: $978-92-893-5664-0$ (print)

ISBN: 978-92-893-5665-7 (electronic)

ISBN: 978-92-893-5666-4 (electronic)

OAI: oai:DiVA.org:norden-5272

DiVA, id: diva2:1219782

Available from: 2018-06-18 Created: 2018-06-17 Last updated: 2018-06-18 
(11) Nordic Council of Ministers

Biodiversity and ecosystem services in Nordic coastal ecosystems: an IPBES-like assessment

\section{Volume 1}

The general overview 


\section{Biodiversity and ecosystem services in Nordic coastal ecosystems: an IPBES-like assessment. Volume 1. The general overview}

Belgrano, A. (Ed.)

Belgrano, A., Clausen, P., Ejdung, G., Gamfeldt, L., Gundersen, H., Hammer, M., Hancke, K., Hansen, J.L.S., Heiskanen, A-S., Häggblom, M., Højgård Petersen A., Ilvessalo-Lax, H., Jernberg, S., Kvarnström, M., Lax, H-G., Køie Poulsen, M., Lindblad, C., Magnussen, K., Mustonen, T., Mäenpää, M., Norling, P., Roth, E., Roto, J., Sogn Andersen, G., Svedäng, H., Söderberg, C., Sørensen J., Tunón, H., Vihervaara, $P .$, Vävare, $S$. 
Biodiversity and ecosystem services in Nordic coastal ecosystems: an IPBES-like assessment. Volume 1. The general overview

Belgrano, A. (Ed.)

Belgrano, A., Clausen, P., Ejdung, G., Gamfeldt, L., Gundersen, H., Hammer, M., Hancke, K., Hansen, .L.S., Heiskanen, A-S., Häggblom, M., Højgård Petersen A., Ilvessalo-Lax, H., Jernberg, S., Kvarnström, M., Lax, H-G., Køie Poulsen, M., Lindblad, C., Magnussen, K., Mustonen, T., Mäenpää, M., Norling, P., Roth, E., Roto, J., Sogn Andersen, G., Svedäng, H., Söderberg, C., Sørensen J., Tunón, H., Vihervaara, P., Vävare, S.

Project-leader: Gunilla Ejdung and Britta Skagerfält.

ISBN 978-92-893-5664-0 (PRINT)

ISBN 978-92-893-5665-7 (PDF)

ISBN 978-92-893-5666-4 (EPUB)

http://dx.doi.org/10.6027/ANP2018-536

TemaNord 2018:536

ISSN 0908-6692

Standard: PDF/UA-1

ISO 14289-1

(c) Nordic Council of Ministers 2018

Cover photo: Kasper Hancke

Print: Rosendahls

Printed in Denmark

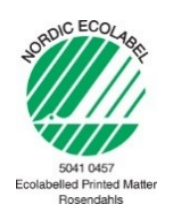

Disclaimer

This publication was funded by the Nordic Council of Ministers. However, the content does not necessarily reflect the Nordic Council of Ministers' views, opinions, attitudes or recommendations.

Rights and permissions

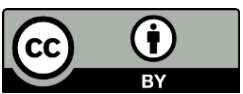

This work is made available under the Creative Commons Attribution 4.0 International license (CC BY 4.0) https://creativecommons.org/licenses/by/4.0

Translations: If you translate this work, please include the following disclaimer: This translation was not produced by the Nordic Council of Ministers and should not be construed as official. The Nordic Council of Ministers cannot be held responsible for the translation or any errors in it. 


\section{Contents}

Foreword

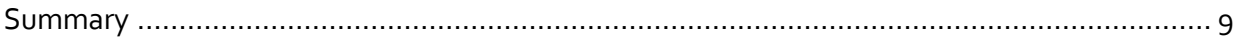

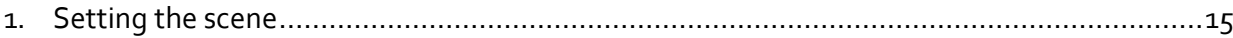

1.1 Context of the Nordic coastal zone assessment ............................................

1.2 Previous assessments and the conceptual "IPBES" framework ..............................17

1.3 The Nordic model for ecosystem assessment ..................................................19

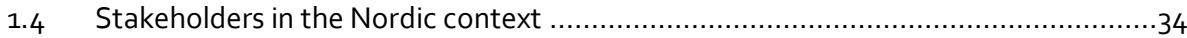

1.5 Introduction to Nordic case studies where the IPBES approach is tested ..................34

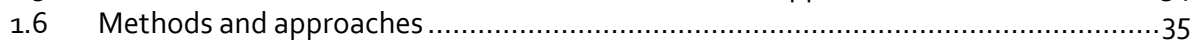

1.7 The structure of the Nordic assessment and the core questions............................... 39

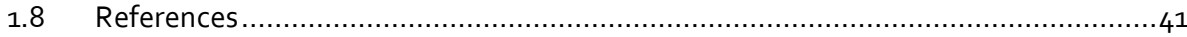

2. Nature's Contributions to People and Human Well-being in a Nordic coastal context ........ 45

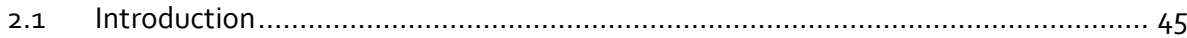

2.2 Relationships and impacts of changes regarding nature's contributions to people .. 48

2.3 Identifying aspects of biodiversity and ecosystem services critical to social relationships, spirituality and cultural identity ........................................... 54

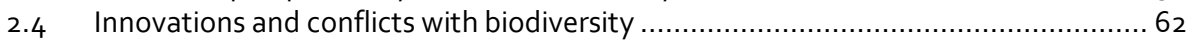

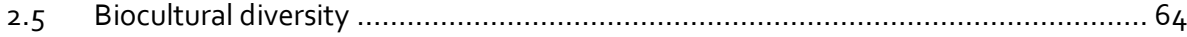

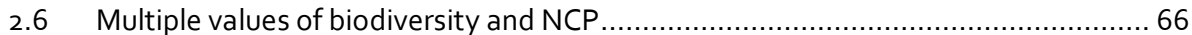

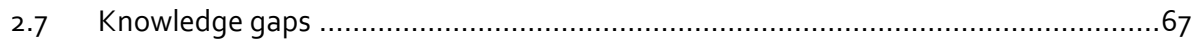

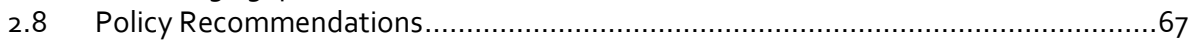

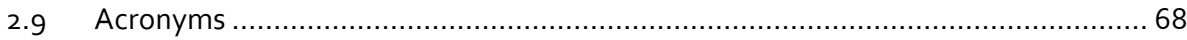

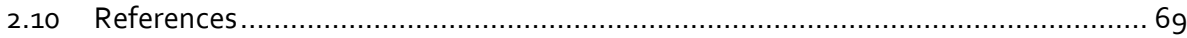

3. Status and Trends of Biodiversity and Ecosystem Function ....................................... 75

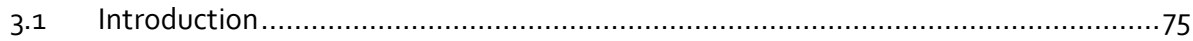

3.2 Defining biodiversity and its importance to Nordic marine life .............................. 77

3.3 Defining Ecosystem function and value to human societies in Nordic countries .......78

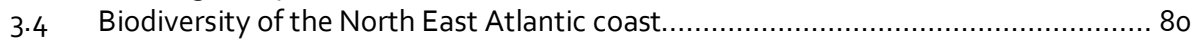

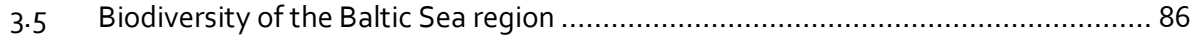

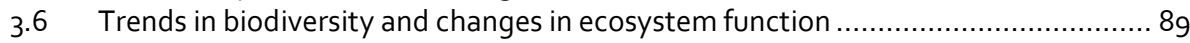

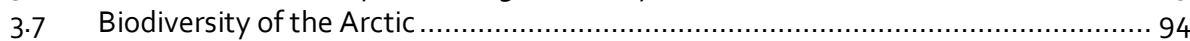

3.8 Differences and similarities between regions ................................................. 96

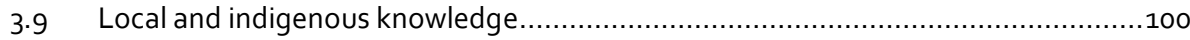

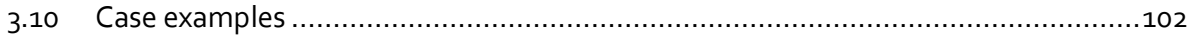

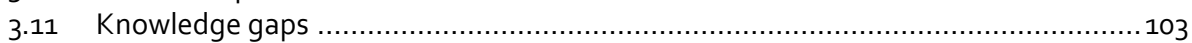

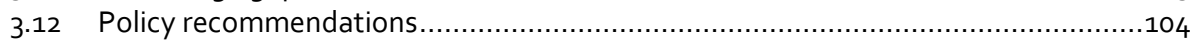

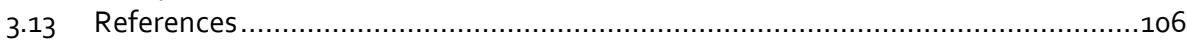

4. Direct and indirect drivers of change indifferent perspectives of human well-being (quality of life)

Introduction .

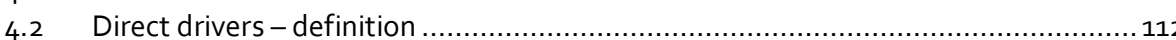

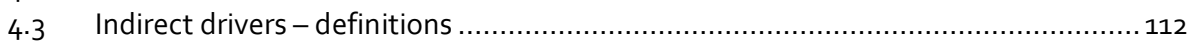

4.4 Past and current trends of direct and indirect drivers of change - a Nordic

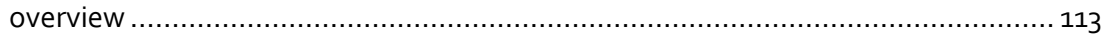

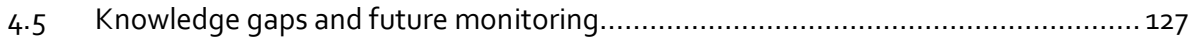

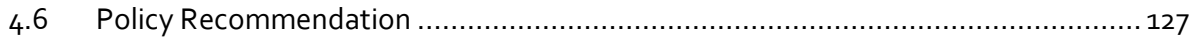

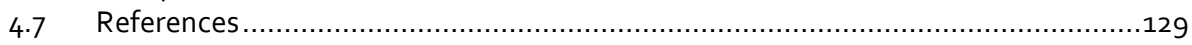


5. Analysis of interactions between Biodiversity (B), Ecosystem Services (ES), and Nature's Contributions to People (NCP) ................................................................133

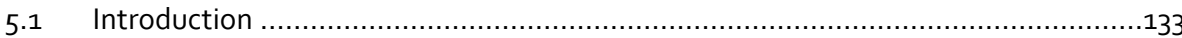

5.2 Qualitative comparative analysis based on expert judgements.......................... 134

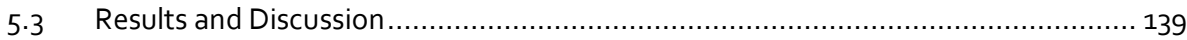

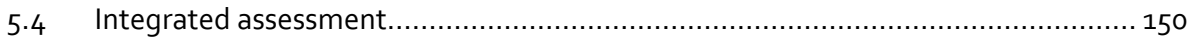

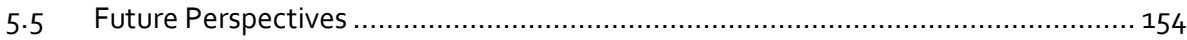

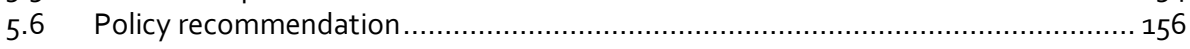

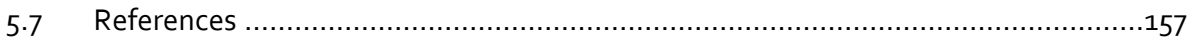

6. Options for governance, institutional arrangements and private and public decision-

making across scales and sectors................................................................... 161

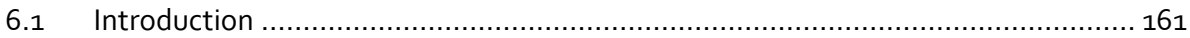

6.2 Framing institutions and policy options for biodiversity and ecosystems governance ....................................................................................... 162

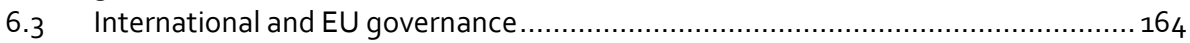

6.4 Formal institutional framework for Nordic governance - comparing WFD implementation in the Nordic region ........................................................ 167

6.5 Mainstreaming biodiversity and ecosystem services across sectors in the Nordic region: Examples from water governance and the case studies ..........................171

6.6 Opportunities and challenges for policy and decision-making ......................... 181

6.7 Detected uncertainties and options for the future ........................................ 183

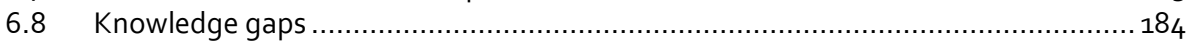

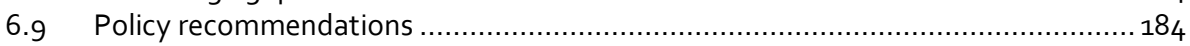

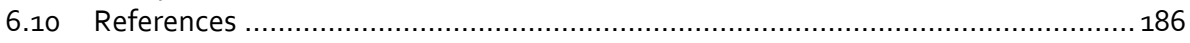

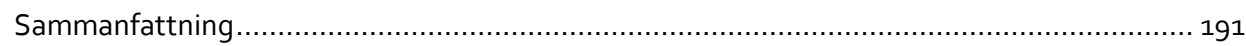

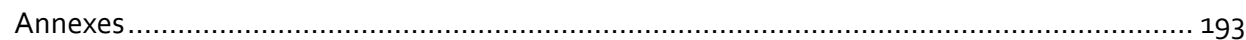

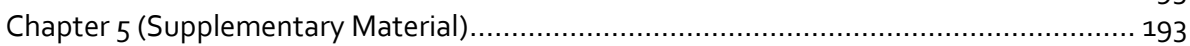

Annex C - List of editors, co-chairs, authors and reviewers ....................................... 193

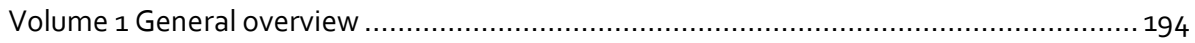




\section{Summary}

This study has been inspired by the Intergovernmental Science-Policy Platform on Biodiversity and Ecosystems Services (IPBES). The aim of the assessment was to describe the status and trends of biodiversity and ecosystems in the Nordic region, including the drivers and pressures affecting these ecosystem components, as well as the effects on people and society and options for governance. Ultimately, this study provided an opportunity to aid the process of utilizing scientific results in the policy and decision-making realm, thus forwarding the science-policy interphase. The Nordic study is structured as closely as possible to the framework for the regional assessments currently being finalized within IPBES. This assessment has been based on information provided by the following case study areas in the Nordic countries: Näätämö/ Neiden basin, Kalix Archipelago, Kvarken/the Quark, Puruvesi Lake in North Karelia, the Lumparn area, Öresund, Helgeland coast, Faroe Islands (Føroyar), Broddanes West Fjords and the coastal areas of Húsavík (Iceland) and Disko Bay (Greenland).

The objectives of the assessment were to address the following questions:

- What are the main drivers and pressures affecting biodiversity, ecosystem services and ecosystem function?

- How does global, regional and national policy influence biodiversity, ecosystem services and human well-being in the Nordic region? What opportunities exist in policy-making?

- How can we better integrate indigenous and local knowledge (ILK) perspectives on biodiversity, ecosystem services and nature's contributions to people (NCP) in decision-making? How can we apply their culture and traditional management methods to support decision-making?

- What opportunities exist for sustainability and nature-dependent human wellbeing in Nordic societies?

- What biodiversity and ecosystem values define NCP in the Nordic coastal region?

- How can data sources such as Earth Observation and GIS spatial data be used in assessments to support decision-making?

- What are the major gaps in data, knowledge, management and decision-making systems? How can these gaps be minimized? 
The outcomes from the assessment has been summarized in the following key messages:

- A. The Nordic coastal region has many natural assets and provides numerous ecosystem services:

- A1. The Nordic coastal region is unique due to the variability in nature types and biodiversity. Its coastal areas support examples of many different habitats spanning the temperate to the Arctic zone. This diversity supports considerable biodiversity that people depend on for their livelihoods;

- A2. The Nordic coastal region contains several globally important species and habitats. These include the wintering bird assemblages in the shallow seas around Denmark, the unique habitats of the Baltic Sea (the largest brackish water area in the world), the kelp forests and breeding seabird colonies on offshore islands and cliffs in northern regions along the Norwegian coast, the recovering populations of whales in the North Atlantic Ocean, the assemblages of Arctic species and the recovering stocks of cod and other species in the North Sea and further north;

- A3. Most of the region's biological value is in the form of large concentrations of fairly common species. The region houses habitats and assemblages of species that are typical of temperate seas warmed by the Gulf Stream, along with the Arctic and the Baltic Seas, parts of which are seasonally frozen. The strong seasonality also results in long and short distance migration of many fish, birds and mammals using the coastal and marine systems in the region. These include globally important winter concentrations of migrant seabirds and shorebirds in the southern part of the region and similarly important summer concentrations in the northern and Arctic regions;

- A4. The ecological status in the North East Atlantic and Bothnian Sea is good. The status is moderate in the Arkona Basin and the Sound, but poor in the Baltic Proper and Gulf of Finland;

- A5. Many biological values of the region are slowly recovering from very low values following past overexploitation. These biological values include populations of fish-eating sea birds and white-tailed eagle, grey heron, crane and several geese species in the Baltic Sea. It also includes cod, herring, mackerel, ringed seal, grey seal, harbor seal, hooded seal, North Atlantic fin whale and bowhead whale along the Norwegian coast, along with wintering and breeding populations of geese and swans in Danish coastal areas. In the Baltic Sea, and particularly in the Bothnian Bay, there is a slow recovery from DDT and PCB pollution events. However, pollution from heavy metals and contamination from persistent toxic chemical and radiation events remains a challenge;

- A6. The network of marine and coastal protected areas is important for preserving biodiversity and ecosystem services in the Nordic region. Regulations to accomplish sustainable use of these areas are under development; 
- A7. The coastal natural resources in the region have provided food for people living in the Nordic region for thousands of years. They continue to provide this today, especially from fisheries in the shallow seas, but also from animals feeding on the coastal habitats and birds breeding on the coastal cliffs. These resources are under various management regimes; some traditional going back at least hundreds of years and others with a more recent natural science basis;

- A8. The diversity of Nordic coastal and marine ecosystems continues to deliver goods and services that are vital to the livelihoods of many people in the region. Beaches and other coastal areas are important leisure resources for tourists from other countries. Particularly holidaymakers and weekend visitors from within the Nordic countries frequent the southern parts of the region. There are also continuing traditions and systems of using coastal and marine resources across the Nordic region. These are integrated into the modern lives of people living both in the rural areas and, increasingly, in cities throughout the region;

- Ag. The Nordic coastal regions support communities with strong traditional ties to nature, which provides opportunities for resource management based on traditional use, management and governance regimes. These communities include both Inuit/ Greenlandic and Saami peoples in the north, coastal communities along the seaboard of Norway, Sweden, Finland and Denmark, as well as populations in the Faroe Islands and Iceland;

- A10. The coastal natural resources of the region provide inspiration for the people living in the Nordic countries. Some are strongly embedded in cultural identities and ways of living. These cultural values provide a powerful bond between people and nature and are a major reason for the persistence, and in some cases recovery, of natural resources in these coastal regions.

- B. The coastal Nordic region is under pressure:

- B1. Some species are still in decline in the region despite conservation actions aiming to assist their recovery. This includes the globally important populations of breeding auks (puffin, razorbill, common guillemot, Brünnich's guillemot) and some breeding seabirds (e.g. kittiwake). There has been a considerable decline in sea grass meadows, kelp forests and fucoid algae/or brown seaweeds in different parts of the region. Due to population crashes in the past century, species like sturgeon and lamprey in the Baltic Sea remain at very low populations;

- B2. The Arctic - also the parts within the Nordic region - is the part of the planet most heavily affected by climate change and is warming at a far higher rate than any other region on earth. This is having and will continue to have dramatic impacts on ecosystems and their services, including through ocean acidification. Throughout the region, there are emerging impacts of climate change. Northern species of birds, fish and bivalves cease to breed in southern countries like Denmark, migrating northward and expanding their 
breeding grounds along the coasts of Norway, Sweden and Finland. Fish e.g. mackerel, herring and tuna, are moving to more northern waters around Iceland and Greenland. There are changes in the coastal food web, potentially impacting food sources for some of the largest marine creatures in the region, e.g. humpback whale. Ocean warming is having negative impacts on the extensive kelp forests in the western oceans off Norway;

- B3. Chemical pollutants, eutrophication and plastics are affecting the coastal waters of the region. The historical heavy industrial and nuclear radiation pollution is still affecting parts of the Baltic Sea. The situation has greatly improved over the past 30 years. In other parts of the region, there is considerable run-off of agricultural fertilizers and pesticides, although the amount has been reduced from past levels. Eutrophication of the coastal waters remains a problem, evidenced by impacts to species composition in many areas. In recent years, fears have emerged on what consequences the high quantities of plastics and nanoparticles in the oceans may lead to. It will take many centuries for these particles to degrade in the regions' colder northern waters, and their impact on marine life is negative;

- B4. Invasive species pose serious challenges to parts of the Nordic coastal ecosystems. Significant challenges arise from the Japanese rose (Rosa rugosa) on coastal foreshores and sand dune areas in Denmark and southern Sweden. Challenges also arise as a result of a variety of invasive marine animals and plants, including the round goby in the Baltic Sea and in the North Sea, and king crab in the Bering Sea. Measures against alien invasive species may mitigate the effects of these species. Such measures may include the implementation of legislation and/or physical measures to remove already established species;

- B5. Infrastructure development in marine and coastal areas poses challenges. The Nordic region is a global frontrunner in near- and offshore wind turbine technological development and installation. However, wind power plants have impacts on e.g. migratory birds and bats. In addition, there are impacts associated with the construction of the large bridges between Denmark and Sweden, and Denmark and Germany. The trend to set aside coastal or nearcoastal areas for building summer cottages brings challenges of reduced access, increased disturbance and the need for water treatment. There is oil and gas exploration and mining industry in the northern seas that has potential to impact these areas. Of particular concern is the slow break-down of pollutants in cold waters of low biological capacity.

- C. Building resilient futures in the Nordic coastal region:

- C1. The political and governance systems of the Nordic region are transparent and fair. There is a broad interest within the Nordic countries to pursue development pathways to reduce local and global impacts on natural resources. There is good access to coastal areas and strong emphasis on the use of nature and natural areas for livelihoods and recreation. These values 
and traditions need to be maintained to continue to provide space for nature and to allow people to benefit from natural coastal areas. Nordic countries are able to implement and maintain systems for improved coastal management and sustainable harvesting of species, habitats and resources;

- C2. There are good examples of indigenous and local peoples participating in coastal nature management in the northern regions. This is critically important for continued subsistence use and for maintaining ecosystem services in the north. Better integration and support of indigenous and local knowledge within conservation management and in governance of resource use in the region would be beneficial;

- C3. Ongoing progress to clean up pollution and reduce eutrophication in rivers, lakes, coastal areas and open seas needs to be continued. This relates to all the countries in the Nordic region and is equally important on national, regional and international scales. This can be achieved through catchment-based management approaches, as eutrophication is mainly caused by run-off from land. There have been intensive efforts to reduce the secondary environmental impacts from the large marine aquaculture industries (e.g. salmon farmed in the Norwegian fjords), shell fish farming (e.g. blue mussels on poles and other structures in Danish and Swedish seas), along with the emerging seaweed farming industries;

- C4. Some fish stocks and populations of marine mammals are recovering in the region. Further recovery can be accomplished through careful review and changes to policies as required. However, some populations (e.g. seals) have recovered to the point where they are causing problems. For those fisheries and populations of marine mammals that are still in decline, further efforts are required to help return populations to a healthy state;

- $C_{5}$. Cooperation among the Nordic countries is needed to improve coastal zone planning and management. Policies and their implementation need to balance the needs of the natural system and human development in coastal areas (e.g. summer houses, urban areas, industry). Examples can be drawn from ongoing marine spatial planning initiatives;

- C6. Coastal resilience to rising seas needs to be enhanced, e.g. through naturebased solutions offered by natural or moderately modified ecosystems. Changes in the coastal regions may be dramatic in the future due to climate change and related sea level rise, flooding, extreme weather events and increased run off from inland water bodies and melting ice;

- C7. The legal frameworks in most Nordic countries have national laws, EU directives and regulations and follow regional marine conventions including HELCOM and OSPAR. These are often developed from agreed targets of international non-binding agreements, such as those under the Convention on Biological Diversity and the United Nations Framework Convention on Climate Change. This legislative framework is strong, but can always be 
further developed to enhance the outcomes for nature and people in the coastal regions.

The following options for policy makers have been proposed:

- Evaluate the costs and benefits of existing environmental policies, prioritise and streamline them to help overcome the high density of policies;

- Where possible, coordinate the implementation of policies across the Nordic region to reduce policy conflicts;

- Identify and adjust policies that counteract incentives for conservation and the sustainable use of biodiversity in coastal areas;

- Increase political focus on the status of marine biodiversity and the influence of human activities on species and habitat diversity. This is closely related to work with the UN Sustainable Development Goals (SDGs);

- Involve science-based assessments and priorities in policymaking in terms of identifying most needed conservation and management policy initiatives;

- Safeguard the right to public access of coastal areas as access to nature maintains access to a number of non-material nature's contributions to people, such as identity, physical and psychological experiences, knowledge and inspiration, as well as material benefits such as food and ornaments. This collectively helps maintain society's sense of duty to protect the environment;

- Implement ecosystem-based adaptation to increase the coastal region's resilience to climate change;

- Draw benefits from technological developments that reduce the region's ecological footprint; and

- Identify pathways to achieve the 2050 vision of the Strategic Plan for Biodiversity and implement the Sustainable Development Goals and their targets. 
Nordic Council of Ministers

Nordens Hus

Ved Stranden 18

DK-1061 Copenhagen K

www.norden.org

\section{Biodiversity and ecosystem services in Nordic coastal ecosystems: an IPBES-like assessment Volume 1. The general overview}

This report describes the status and trends of biodiversity and ecosystem services in the Nordic region, the drivers and pressures affecting them, interactions and effects on people and society, and options for governance. The main report consists of two volumes. Volume 1 The general overview (this report) and Volume 2 The geographical case studies. This study has been inspired by the Intergovernmental Science-Policy Platform on Biodiversity and Ecosystems Services (IPBES). It departs from case studies (Volume 2, the geographical case studies) from ten geographical areas in the Nordic countries (Denmark, Finland, Iceland, Norway, Sweden) and the autonomous areas of Faroe Islands, Greenland, and Åland. The aim was to describe status and trends of biodiversity and ecosystem services in the Nordic region, including the drivers and pressures affecting these ecosystems, the effects on people and society and options for governance. The Nordic study is structured as closely as possible to the framework for the regional assessments currently being finalized within IPBES. The report highlights environmental differences and similarities in the Nordic coastal areas, like the inhabitants' relation to nature and the environment as well as similarities in social and policy instruments between the Nordic countries. This study provides background material for decision-making and it is shown that Nordic cooperation is of great importance for sustainable coastal management and should be strengthened in future work. 